\title{
Functional Food and Bioactive Compounds on the Modulation of the Functionality of HDL-C: A Narrative Review
}

\author{
Karla Paulina Luna-Castillo ${ }^{1} \mathbb{D}^{\text {, Sophia Lin }}{ }^{2} \mathbb{D}$, José Francisco Muñoz-Valle ${ }^{1,3} \mathbb{D}^{\mathbb{D}}$, Barbara Vizmanos ${ }^{1,4} \mathbb{D}^{\text {, }}$

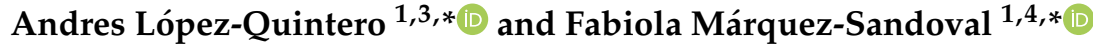

1 Doctorado en Ciencias de la Nutrición Traslacional, Departamento de Clínicas de la Reproducción Humana, Crecimiento y Desarrollo Infantil, Centro Universitario de Ciencias de la Salud, Universidad de Guadalajara, Guadalajara 44340, Mexico; karla.luna3337@alumnos.udg.mx (K.P.L.-C.); drjosefranciscomv@cucs.udg.mx (J.F.M.-V.); bvizmanos@yahoo.com.mx (B.V.)

2 School of Population Health, University of New South Wales, Sydney, NSW 2052, Australia; sophia.lin@unsw.edu.au

3 Instituto de Investigación en Ciencias Biomédicas (IICB), Centro Universitario de Ciencias de la Salud, Universidad de Guadalajara, Guadalajara 44340, Mexico

4 Instituto de Nutrigenética y Nutrigenómica Traslacional, Centro Universitario de Ciencias de la Salud, Universidad de Guadalajara, Guadalajara 44340, Mexico

* Correspondence: andres.lopezq@academicos.udg.mx (A.L.-Q.); yolanda.marquez@academicos.udg.mx (F.M.-S.); Tel.: +52-33-1058-5200 (ext. 33704) (A.L.-Q.)

\section{check for} updates

Citation: Luna-Castillo, K.P.; Lin, S.; Muñoz-Valle, J.F.; Vizmanos, B.; López-Quintero, A.; MárquezSandoval, F. Functional Food and Bioactive Compounds on the Modulation of the Functionality of HDL-C: A Narrative Review. Nutrients 2021, 13, 1165. https:// doi.org/10.3390/nu13041165

Academic Editor:

Francesca Giampieri

Received: 7 March 2021

Accepted: 29 March 2021

Published: 1 April 2021

Publisher's Note: MDPI stays neutral with regard to jurisdictional claims in published maps and institutional affiliations.

Copyright: (c) 2021 by the authors. Licensee MDPI, Basel, Switzerland. This article is an open access article distributed under the terms and conditions of the Creative Commons Attribution (CC BY) license (https:// creativecommons.org/licenses/by/ $4.0 /)$.

\begin{abstract}
Cardiovascular diseases (CVD) remain a serious public health problem and are the primary cause of death worldwide. High-density lipoprotein cholesterol (HDL-C) has been identified as one of the most important molecules in the prevention of CVD due to its multiple anti-inflammatories, anti-atherogenic, and antioxidant properties. Currently, it has been observed that maintaining healthy levels of HDL-C does not seem to be sufficient if the functionality of this particle is not adequate. Modifications in the structure and composition of HDL-C lead to a pro-inflammatory, pro-oxidant, and dysfunctional version of the molecule. Various assays have evaluated some HDL-C functions on risk populations, but they were not the main objective in some of these. Functional foods and dietary compounds such as extra virgin olive oil, nuts, whole grains, legumes, fresh fish, quercetin, curcumin, ginger, resveratrol, and other polyphenols could increase HDL functionality by improving the cholesterol efflux capacity (CEC), paraoxonase 1 (PON1), and cholesteryl ester transfer protein (CETP) activity. Nevertheless, additional rigorous research basic and applied is required in order to better understand the association between diet and HDL functionality. This will enable the development of nutritional precision management guidelines for healthy HDL to reduce cardiovascular risk in adults. The aim of the study was to increase the understanding of dietary compounds (functional foods and bioactive components) on the functionality of HDL.
\end{abstract}

Keywords: HDL; dietary compounds; polyphenols; functional food; bioactive compounds; cardiovascular disease; high-density lipoprotein functionality; HDL functionality

\section{Introduction}

Cardiovascular diseases (CVD) remain a serious public health problem and are a primary cause of death worldwide [1]. Global mortality trends from CVD have increased over the last 10 years by $6.4 \%$ from 225.41 to 239.9 per 100,000 between 2009 and 2019 [2]. Several studies have indicated that healthy HDL-C levels (40-60 mg/dL in men, 50$60 \mathrm{mg} / \mathrm{dL}$ in women) [3] are associated with a lower risk of incident CVD [4-6], while low levels of HDL-C ( $<35 \mathrm{mg} / \mathrm{dL}$ in each sex) have been associated with an increased risk [3,5,7]. According to the National Health and Nutrition Examination Survey 2015-2018 in the United States, the prevalence of low HDL-C among adults over 19 aged was 17.2\% in 2015-2018 and was higher among aged 20-29 by $17.6 \%$ and $40-59$ aged by $18.5 \%$ and 60 and over by $14.6 \%$ [8]. Similarly, European [9], Asia [10], and Africa [11] populations have 
a prevalence of $22.1 \%$ (50 years or older), $20.4 \%$ (18-69 years), and $28.6 \%$ (28-73 years), respectively. Further, in Latin America, the reported prevalence of low HDL-C is higher by $27.5 \%$ in young people, higher among aged 29 and over by $29.5 \%$ [12]. This type of dyslipidemia is the commonest form worldwide. However, maintaining healthy HDL-C levels does not seem to be sufficient in lowering CVD risk if the functionality of this particle is not adequate, especially its cholesterol efflux capacity (CEC). This lipoprotein is essential in several cardioprotective mechanisms, including reverse cholesterol transport (RCT), $\mathrm{CEC}$, stimulation of endothelial nitric oxide (NO) (vasodilatory capacity), inhibition of reactive oxygen species (ROS) and decreasing low-density lipoprotein cholesterol (LDL-C) oxidation (antioxidant capacity) and inhibiting the expression of adhesion molecules on endothelial cells [13-16].

Modifications in the structure and composition of HDL-C in the body can result in dysfunctional particles, losing its atheroprotective properties and developing pro-inflammatory and pro-oxidant characteristics $[14,17,18]$. Risk factors for abnormal HDL-C include lowgrade inflammation $[13,14,19]$, acute phase response [20], diabetes [21], obesity, ethnicity [22], and poor-quality diet [23,24]. Exercise is related to the improvement in HDL concentrations and functionality $[25,26]$, while diet can have both positive and negative effects on HDL-C functionality $[24,27,28]$. Studies have shown that a healthy diet, characterized by high consumption of fruits, vegetables, legumes, fish, nuts, and olive oil, could increase the number of HDL-C particles $[27,29,30]$. Dietary functional food in the Mediterranean diet (MD), such as olive oil, whole grains, nuts, legumes, and fish, could contribute to increased CEC, HDL-C esterification index, and paraoxonase 1 (PON1) activity, according to a subsample from the PREDIMED Study (PREvención con DIeta MEDiterránea) [27,29].

In the last 10 years, there has been increasing evidence for the benefits of functional foods and bioactive compounds on CEC, PON1 activation and expression, and cholesteryl ester transfer protein (CETP) activity. Nonetheless, there is currently insufficient evidence to inform the development of a precision nutritional guideline for the treatment and prevention of HDL concentration and functionality. According to the current American College of Cardiology / American Heart Association (ACC/AHA) [31] and European Society of Cardiology (ESC) and European Atherosclerosis Society (EAS) Guidelines for the management of dyslipidemias, no specific goals for HDL-C levels have been determined in clinical trials, although increases in HDL-C predicts atherosclerosis, and low HDL-C is associated with incident and mortality in coronary artery disease, even at low LDL concentrations [32,33].

Experts in the areas of nutrition and metabolism, genetics, as well as immunology are represented in this narrative review. It serves as an integrative approach to figure out the importance of HDL-C in the pathophysiology of CVD, its atheroprotective properties, and the current research about the dietary compounds which contribute to increased HDL-C functionality. Therefore, we overviewed the HDL-C principal cardioprotective properties in halting the progression of atherosclerosis and the structural and functional changes to which the HDL particle may be exposed during inflammation. Moreover, the main aim was to present the available evidence to increase the understanding of dietary compounds (functional foods and bioactive components) on the functionality of HDL (CEC, PON1 activation and expression, CETP activity, and expression of adhesion molecules).

\section{Materials and Methods}

The methodological approach for the present narrative review was performed using the PubMed ${ }^{\circledR}$ and Web of ScienceTM databases updated to 24 March 2021. The search was carried out from February 2020 to March 2021. Search terms included in the title and abstract were "(antioxidants or functional foods or bioactive compounds) AND HDL functionality", "(antioxidants or functional foods or bioactive compounds) AND cholesterol efflux", "(antioxidant or functional foods for bioactive compounds) AND (PON1 or paraoxonase 1) AND HDL", "(antioxidants or functional foods or bioactive compounds) AND (CETP or cholesteryl ester transfer protein)" and "(Antioxidants or functional foods or bioactive compounds) AND endothelial markers and HDL". For specific food and dietary 
compounds (identified in the first scrutiny) the following terms were also applied after the dietary compound name AND: "HDL functionality"; "cholesterol efflux capacity"; "CETP OR cholesterol ester transfer protein"; "PON1 OR paraoxonase 1"; "adhesion molecules"; "VCAM"; "ICAM"; "E-selectin". This narrative review represents a summary of evidence of the last 10 years (2011-2021). Hand-searching of the reference list of each article was conducted to ensure that no important research articles were missed. We highlight the included clinical trials were screened to the more recent publications, in the last 5 years, in order to show the latest evidence oriented to translational knowledge in humans.

We selected all studies in English full text, available in human studies, in vivo and in vitro studies, with main results about one or more of the four HDL-C functions: (1) the inhibition of the oxidation of oxidized LDL (ox-LDL) through the activity of PON1, (2) the CETP activity, (3) the CEC, and (4) the inhibition of the expression of adhesion molecules (VCAM-1, ICAM-1, E-selectin). The methodology and eligibility of all articles were analyzed carefully by the authors. The lack of consistency to relate the dietary compounds and HDL-C functionality was considered an exclusion criterion.

This review was not conducted systematically because there was not enough consistent evidence about this topic.

\section{Pathophysiology of Cardiovascular Disease and HDL}

The leading cause of CVD incidence and mortality is atherosclerosis [34], a chronic inflammatory disease characterized by the hardening of the arterial walls, due to the progressive accumulation of lipid plaques and inflammatory cells within the intima of the large and mid-sized arteries, resulting in decreased or absent blood flow [35-37].

The atherosclerosis processes include the formation of fatty streaks, atheroma, and atherosclerotic plaques (Figure 1) [38].

The first observable event in the process of atherosclerosis is the accumulation of plaque (lipids, calcium, and fibrin) [39]. Hypercholesterolemia results in the internalization of lipids, especially LDL-C in the intima, creating changes in the permeability of the arterial endothelium with concomitant endothelial dysfunction $[35,36]$. The vascular endothelium is a semipermeable barrier that, under normal conditions, controls the diffusion of plasma molecules and regulates vascular tone, inflammation, and prevents thrombus formation. A dysfunctional endothelium results in the loss of these functions [35]. These factors lead to cell oxidation of the trapped particles [38]. Ox-LDL stimulates the local secretion of cytokines, activating leukocyte migration to the intima. Thus, circulating monocytes and T-cells are recruited to attach to the vascular endothelium and adherence to endothelial cells that express adhesion molecules. These include intercellular adhesion molecule-1 (ICAM-1), vascular adhesion molecule-1 (VCAM-1), selectins, and chemotactic signals like monocyte chemoattractant protein 1 (MCP-1), IL-8, and gamma interferon-inducible protein 10. The endothelial cells then infiltrate into the intima (Figure 1A) $[35,36]$. In the initial injury, HDL-C participates with the inhibition of the expression of adhesion molecules: VCAM-1, ICAM-1 and E-selectin (encoded by VCAM1, ICAM1 and SELE genes, respectively). (Figure 1B, orange rounded rectangle and red minus sign).

After penetrating the arterial wall in response to chemotaxis, monocytes are stimulated by the macrophage colony-stimulating factor (M-CSF) that increases their expression of collecting receptors. M-CSF uptake ox-LDL during the monocyte-to-macrophage differentiation to foam cells, promoting plaque progression (Figure 1B) [35,38]. Accumulation of foam cells on the arterial walls contributes to the formation of lipid streaks in early steps $[35,38]$. Some foam cells undergo apoptosis during the intima lesion, producing a lipid-rich necrotizing nucleus in the atherosclerotic plaque. Macrophage foam cells can also produce cytotoxic substances such as tumor necrosis factor (TNF), growth factor, pre-coagulation substances (tissue factors), reactive oxygen species (ROS), such as superoxide anion $\left(\mathrm{O}_{2-}\right)$, and free radicals, which lead to more endothelial damage [38]. These substances further stimulate vascular smooth muscle cell migration from the media into the intima, where they divide and produce extracellular matrix components such as 
collagen and fibrous caps [35]. Particles of HDL-C in this phase can increase CEC and the inhibition of the oxidation of ox-LDL through the activity of PON1 (Figure 1B, orange rounded rectangle and green plus sign).

In later stages, calcification can occur, and fibrosis could appear (Figure 1C) [38]. The progression of atherosclerotic plaques is also characterized by a decrease in vascular smooth muscle cells and the formation of immature and leaking vessels, increasing its susceptibility to rupture. The alterations on the plaque initiate platelet adhesion and activation of the coagulation cascade, allowing the formation of thrombus and clinical manifestations of atherosclerotic diseases such as acute myocardial infarction or sudden death [35,40]. HDL-C has also an important role in this part: it encourages a decrease in the CETP activity (Figure $1 \mathrm{C}$, orange rounded rectangle and red minus sign).

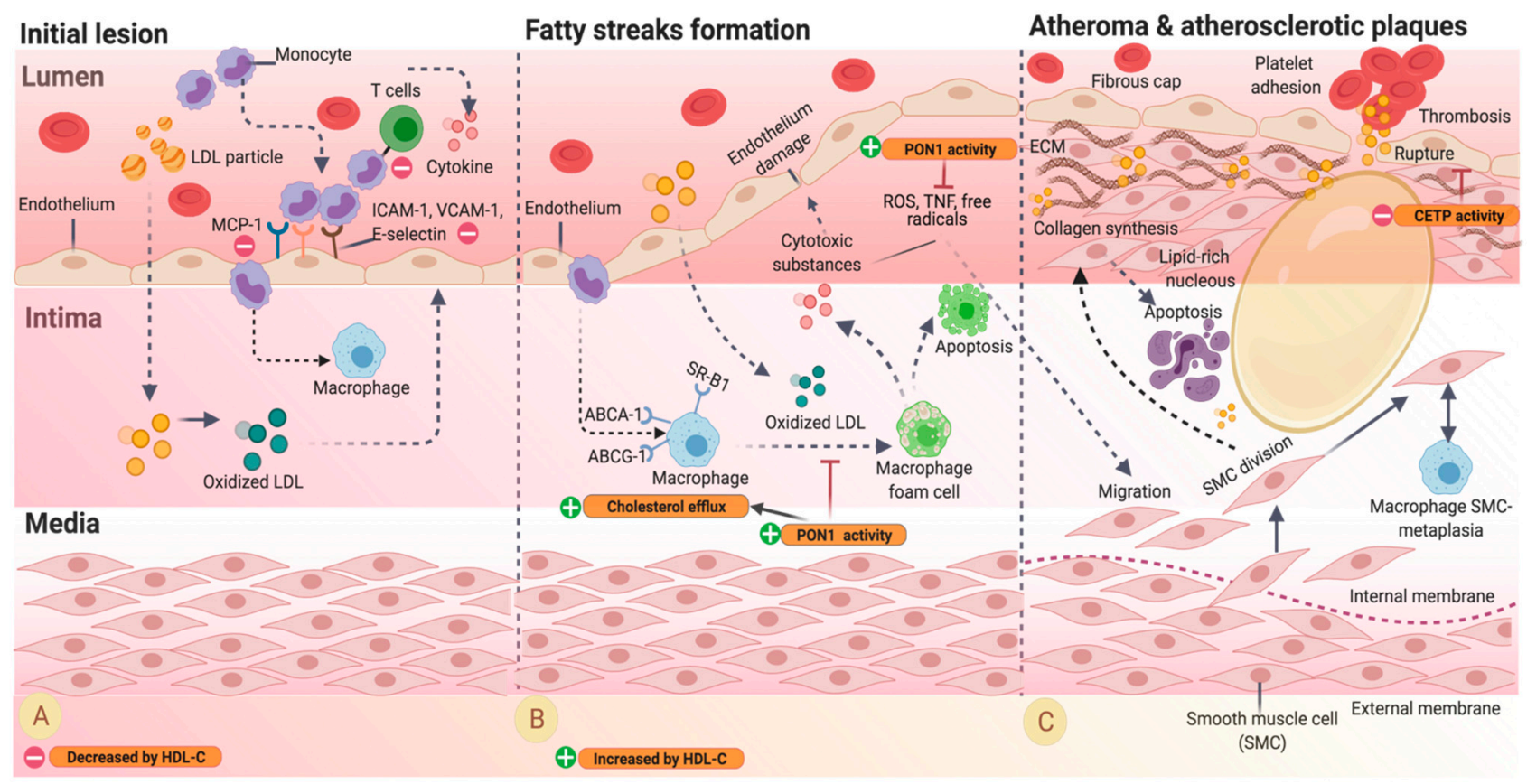

Figure 1. Progression of atherosclerosis adapted from [19,40-42]. (A) The excess of LDL-C particles in the vascular endothelium results in the internalization of lipids in the intima, which are oxidized, stimulating local activating leukocyte migration to the intima. Oxidized LDL-C triggers adhesion molecules, including ICAM-1, VCAM-1, E-selectin, and MCP-1 in the endothelial cells during the first steps of the lesion. HDL-C inhibits the expression of adhesion molecules (VCAM-1, ICAM-1, E-selectin) (orange rounded rectangle and green plus sign). (B) After penetrating the arterial wall, monocytes uptake ox-LDL, and form a macrophage foam cell, contributing to the formation of lipid streaks. HDL-C inhibits the oxidation of ox-LDL through the activity of PON1. (C) Cytotoxic substances stimulate smooth muscle cells (SMC) migration into the intima where it is divided to synthesize collagen, and the extracellular matrix (ECM) creates a fibrous cap and stabilizes the plaque. HDL-C decreases CETP activity, which improves the stability of the plaque and to avoid the formation of thrombus. Abbreviations: LDL-particle, low-density lipoprotein particle; ICAM-1, intercellular adhesion molecule 1; VCAM-1, vascular adhesion molecule 1; MCP-1, macrophage chemoattractant protein 1; ABCA-1, ATP-binding cassette transporter A member 1; ABCG-1, ATP-binding cassette transporter G member 1; SR-B1, scavenger receptor class B type 1; ROS, reactive oxygen species; TNF, tumor necrosis factor; SMC, smooth muscle cells.

\section{HDL-C Physiology and Pathophysiology}

Current evidence suggests that maintaining healthy HDL-C levels is insufficient when circulating HDL-C is dysfunctional $[15,43]$. The main cardioprotective properties of HDL are the CEC $[6,13,44]$, the inhibition of the oxidation of ox-LDL through the activity of PON1, the inhibition of the expression of adhesion molecules (VCAM-1, ICAM-1, E-selectin), and the CETP activity $[24,45,46]$.

HDL-C particles and apolipoprotein A-I (apoA-I) confer protection against atherosclerosis through different pathways and mechanisms $[15,43]$. The most recognized and 
studied cardioprotective property associated with HDL-C molecules is their key function in RCT [6,44], that is, HDL-C particles capacity to transport cholesterol from extrahepatic tissues to the liver for processing or excretion from the body $[6,47,48]$. RCT includes two main steps; the first one, lipid-free, or lipid-poor apoA-I (pre- $\beta$ HDL), binds to ATP-binding cassette transporter A member 1 (ABCA-1) in macrophages and accepts cholesterol from membranes of lipid-loaded cells of the arterial wall [44,49]. The release of free cholesterol on HDL surfaces is esterified by lecithin cholesterol acyltransferase (LCAT) and generates a mature HDL particle ( $\alpha$-HDL). RCT is completed at the last step when esterified cholesterol is delivered to the liver by the binding scavenger receptor class B type 1 (SR-B1) [44].

In particular, the macrophage cholesterol efflux (CE), a small part of the RCT [13], is characterized by the ability of HDL-C to extract excessive cholesterol from peripheral membranes from macrophages and foam cells. This function is carried out by different mechanisms involving transporters such as ATP-binding cassette transporter A member 1 (ABCA-1), ATP-binding cassette subfamily G (ABCG-1), and ATP-binding cassette subfamily G member 4 (ABCG-4) [50,51]. The macrophage CE is mediated most effectively by cholesterol-deficient and phospholipid-deficient apoA-I complexes and by very small HDL particles [15].

There are other potentially favorable properties of HDL-C including anti-inflammatory, antithrombotic, and antioxidant effects $[24,45,46]$. HDL-C can also reduce endothelial dysfunction [15] with additional antiatherogenic and antioxidant properties by inhibiting LDL-C oxidation and stimulating the synthesis of nitric oxide (NO), a powerful vasodilator, and inhibiting reactive ROS $[15,17]$. Therefore, HDL can decrease the thrombotic risk associated with increased synthesis and bioavailability of endothelial NO and prostacyclin, preventing platelet activation, decreasing thrombin generation, and consequently downregulating platelet aggregation, and as a precursor of fibrin synthesis [52]. Another anti-inflammatory action of HDL-C is the hydrolysis of lipids oxidized by enzymes associated with HDL-C, such as platelet-activating factor-acetylhydrolase (PAF-AH), PON-1, apoA-I, LCAT, and CETP $[46,53]$. HDL-C has been shown to protect against LDL-C oxidation by preventing the generation of pro-inflammatory lipids such as lipid hydroperoxides and oxidized phospholipids [54]. In particular, PON1 appears to be responsible for decreasing the intensity of oxidative damage to macrophages, stimulating the cholesterol flow, and attenuating the oxidative stress in atherosclerotic lesions [55].

Furthermore, HDL reduces coronary atherosclerosis by decreasing expression of VCAM1, ICAM1 and SELE genes in endothelial cells, key mediators in the passage of immunocompetent cells from the blood capillaries to the inflammation site in the arterial wall, thereby reducing inflammation and inhibiting the oxidation of LDL-C $[17,56]$. There is additional evidence that HDL-C associated with proteins such as apoAII, apoAIV, apoJ, and apoF can inhibit the expression and circulating levels of VCAM-1, ICAM-1, and Eselectin [57]. HDL-C modulates the chronic inflammatory response, inhibiting IL-1 $\beta$ and $\mathrm{TNF} \alpha$ production by blocking the interaction of monocytes with activated T cells, the primary mechanism of monocyte stimulation $[17,58,59]$. Contact between activated T cells and monocytes or macrophages drives the production of several cytokines (IL-1 $\beta$, IL-6, IL-8, MCP1, and TNF $\alpha$ ), responsible for atherogenesis and tissue destruction $[17,59]$. In the same way, HDL-C may attenuate the dysregulated apoptosis of atherosclerotic plaque cells by inhibiting macrophage and endothelial cell apoptosis by different stimulations [44].

Other cardioprotective capacities of HDL-C have been related to HDL-lipoproteinassociated phospholipase A2 (HDL-LpPLA2). The activity of HDL-LPPLA2 has been associated with lower cardiovascular risk in clinical studies [60]. Moreover, LpPLA2 when bound to LDL exerts pro-inflammatory and atherogenic effects [61]. The complexity of HDL-C remodeling regarding the structure, size, shape, and density characteristics has been previously described [62]. There exist multiple classifications according to the employed techniques. Respecting shape, alpha subfractions (alphaHDL) are actively involved in the $\mathrm{RCT}$, and they represent the most abundant circulating HDL-C particles (Figure 2). HDL subfractions confer different properties that are inherent to their composition $[63,64]$. 


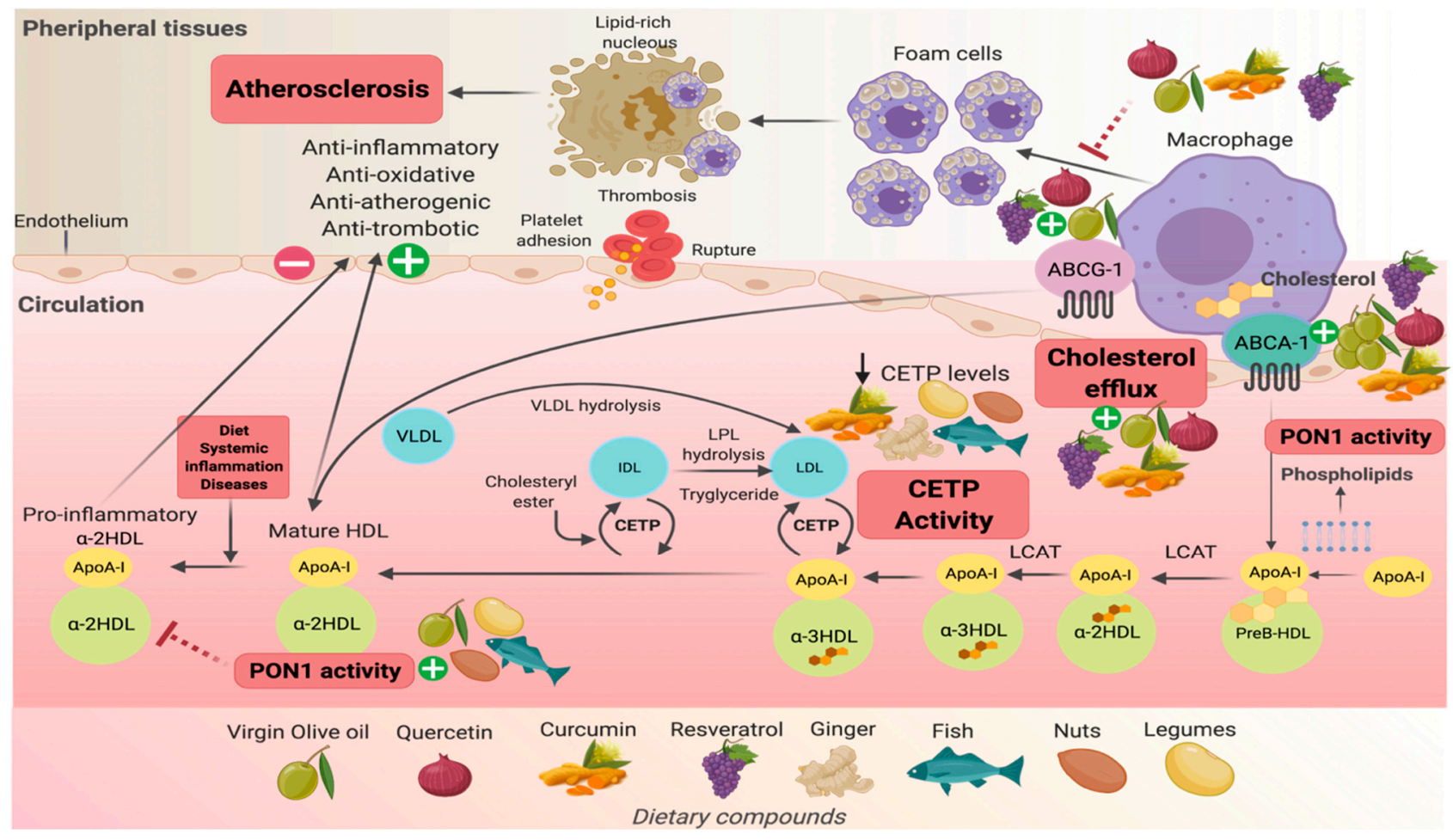

Figure 2. Molecular mechanism of functional foods that enhance HDL functionality adapted from [65,66]. Virgin olive oil, quercetin, and resveratrol participate and contribute to the improvement of cholesterol efflux from macrophages by increasing the expression of $A B C G 1$ and $A B C A 1$ transporters, while curcumin only influences the $A B C A 1$ transporter. All of these mechanisms would prevent the accumulation of cholesterol within macrophages in the arterial wall, and its subsequent relationship with the progression of atherosclerosis. Quercetin is related to the increase in PON1 protein and its expression, improving the anti-oxidant, anti-inflammatory, and anti-atherogenic activity of HDL. Abbreviations: ABCG-1, ATP-binding cassette sub-family G member 1; ABCA-1, ATP binding cassette subfamily A member 1; PON1, paraoxonase 1; CETP, cholesteryl ester transfer protein; LCAT, lecithin-cholesterol acyltransferase; HDL, high-density lipoprotein; LDL, low-density lipoprotein; VLDL, very-low-density lipoprotein; IDL, intermediate-density lipoprotein.

\subsection{Factors That Impact the Function of HDL}

Functionality and composition of HDL-C particles can be affected under certain circumstances [13] such as the acute phase response after infection, chronic low-grade inflammation, acute myocardial infarctions, atherogenesis [20], diabetes mellitus, obesity, and metabolic syndrome (MS) [21,22], ethnicity [22], smoking [15], and diet [23,67]. All these factors can produce an atherogenic and pro-inflammatory HDL-C, in other words, HDL-C can become dysfunctional $[15,19,24]$.

Dysfunctional lipoprotein results from the alteration of the proteins, enzymes, or transporters involved in HDL metabolism, which affects the process of maturation and remodeling of HDL [44]. Modifications in arginine, lysine, and methylglyoxal, covalently modified proteins by non-enzymatic glycation reactions, have been related to the loss of apoA-I ability to activate LCAT. The latter results in the inability of apoA-I to inhibit the infiltration of neutrophils into the intima of the carotid arteries in animal models. Exposure of the recombinant HDL-C to methylglyoxal resulting in the loss of anti-inflammatory activities, as occurs in apoA-I, produces dysfunctional HDL-C $[17,68,69]$.

Similarly, myeloperoxidase (MPO), a heme protein overexpressed in human atherosclerosis lesions, can damage HDL-C particles. High levels of MPO have been detected during the progression of atherosclerosis [44]. Lipid-free apoA-I is oxidized by MPO in vitro, and the macrophage $\mathrm{CE}$ by ABCA-1 pathway is decreased. Oxidation of methionine in apoA-I associated with HDL-C also disturbs the capacity to activate LCAT [43]. 


\subsection{Effect of Inflammation on $H D L$}

During inflammation, HDL-C has been found to undergo significant changes in size, composition, and structure. Some enzymes participate in the remodeling of HDL-C due to inflammation, specifically serum amyloid A (SAA) and secretory phospholipase A2 (sPLA2-IIA) [15,18].

The reduction in HDL-C concentration during the acute response has been linked to two main mechanisms: the decrease in the liver synthesis of apoA-I [17] and the replacement of apoA-I with SAA in HDL-C particles, due to its overexpression through transactivation of nuclear activation factor-kappa $\beta$ (NFk- $\beta$ ). This last mechanism modifies the expression of apoA-I and PON1, inhibits the activation of peroxisome proliferation-activated receptors (PPARs), which convert the HDL-C into an inflammatory particle, reducing its ability to inhibit LDL oxidation $[14,15,18]$. Additionally, lipopolysaccharides (LPS) and inflammatory cytokines inhibit cholesterol output from cells by reducing the expression of the $A B C A-1$ gene and increasing the concentration of intracellular cholesterol. Interleukin 1 (IL-1) also reduces the expression of PPAR and liver $\mathrm{X}$ receptor (LXR) [70].

SAA is associated with an inflammatory response mechanism, from the stimulation the production of inflammatory factor as monocytes and macrophages and immune cells migrations as MCP-1 in human monocytes, causing the vascular inflammation by expression of oxidized LDL receptor 1 [17]. Together, this process contributes to the development of atherosclerotic plaque.

Inflammation promotes a reduction in LCAT activity. During the acute phase response and inflammation, there is a reduction in mRNA expression and CETP and phospholipidtransfer protein (PLTP) activity, contributing to changes in HDL-C metabolism and function $[70,71]$. In the same way, there is a reduction in the antioxidant capacity due to a decrease in other proteins associated with HDL: PON1 and PAF-AH [44].

All changes in RCT enzymes lead to lower HDL-C levels that have faster catabolism and are removed from circulation [70]. This produces deterioration in one of the main functions of HDL-C, the RCT capacity [44], a function considered an important atherogenic protector [14,72]. A reduction in HDL-C and phospholipids could induce changes as a compensatory response which results in higher synthesis and accumulation of phospholipidrich VLDL. In consequence, hypertriglyceridemia appears [70].

The aforementioned changes could explain some patients showing low levels of apoAI and HDL-C after an inflammatory response [70]. Inhibition of LXR activity mediated by toll-like receptors (TLR) produces cholesterol accumulation in the vessel wall, which causes an accumulation of cholesterol-laden macrophages, causing a pro-atherogenic effect and early atherosclerotic injury [70].

Finally, alterations in function, structure, and composition of HDL-C particles may reduce $\mathrm{CEC}$, antioxidant properties, and increase atherogenic effects [73].

\section{Dietary Compounds and Their Effects on the Modulation of HDL-C Functionality}

The most recent ACC/AHA 2019 Guidelines for the primary prevention of CVD recommend a healthy diet, which is characterized by high consumption of vegetables, fruits, legumes, nuts, whole grains, and fish; replacement of saturated fatty acids (SFA) with polyunsaturated fatty acids (PUFAs) and monounsaturated fatty acids (MUFAs); a reduced intake of sodium to $<2400 \mathrm{mg} /$ day; minimizing the consumption of processed meats, refined carbohydrates, and sweet drinks; and limit the consumption of trans fats. To achieve these recommendations, the AHA/ACC advocates for plant-based dietary patterns such as the vegetarian diet (VD) and the Mediterranean diet [31]. On the other hand, the current ES/EAS Guidelines for the management of dyslipidemias specify lifestyle modifications to improve HDL-C concentration and the available evidence on the effect of functional foods on improvements in overall lipoprotein profile concentrations [32].

Despite this, there is not enough evidence of the direct impact of these nutritional recommendations on HDL-C functionality. The effect of some of these recommendations has only been assessed concerning HDL-C concentrations $[16,30,74]$. 
Virgin olive oil, quercetin, and resveratrol participate and contribute to the improvement of cholesterol efflux from macrophages by increasing the expression of $A B C G 1$ and $A B C A 1$ transporters [75-78], while curcumin only influences the ABCA-1 transporter [79]. All of these mechanisms would prevent the accumulation of cholesterol within macrophages in the arterial wall, and its subsequent relationship with the progression of atherosclerosis. Additionally, it has been shown that curcumin, ginger, legumes, nuts, and fish can contribute to reductions in plasma CETP [80,81]. This enzyme participates in the transferring of cholesteryl esters from HDL participles to triglyceride-poor proteins, and high levels of CETP are related to CVD [82]. PON1 expression improves the anti-oxidant, anti-inflammatory, and anti-atherogenic activity of HDL-C. Therefore, functional foods could contribute to the modulation and prevention of atherosclerosis [16] (Figure 2).

In the present paper, we summarize the evidence on HDL functionality (CEC, CETP activity, and its antioxidant capacity by PON1 activity) as well as its expression and relationship with functional foods (extra virgin olive oil [27,81,83-85], whole grains [81], nuts $[27,81,86,87]$, legumes [81,88], fresh fish [81,89,90], red wine [91]), fruits and vegetables [92-95], ginger [80], green tea [91,96], cocoa [91,97], and bioactive compounds as curcumin $[79,80]$, resveratrol $[78,98]$, and quercetin $[75,76,99]$.

At the moment, the evidence of dietary compounds and adhesion molecules expression is focused exclusively on an inflammatory response in a broad context, and there is no connection with the importance of HDL functionality. In this sense, the inhibition of the expression of adhesion molecules is not analyzed to narrow down the presented information in this narrative review [100-102].

\subsection{Cholesterol Efflux Capacity}

One of the main elements related to atherosclerosis progression is the accumulation of cholesterol into macrophages in the arterial wall, contributing to the formation of foam macrophages [103]. RCT is one of the main properties of HDL-C; it is necessary to transport accumulated cholesterol to the liver for excretion [47]. A phase of the RCT considered a fundamental aspect of atheroprotection is CEC, which refers to HDL-C's ability to extract cholesterol from peripheral membranes, macrophages, and foam cells $[50,104]$ by different transporters such as ABCA-1, ABCG-1, or SR-B1 [47]. CEC is used as a marker to measure HDL-C functionality [13].

There is evidence in the literature of functional foods and/or bioactive substances related to CEC, such as extra virgin olive oil [27,81,83,84], fruits [92,93], nuts [87], legumes [88], fish [89,90], quercetin [75,76], green tea, cocoa [91,97], red wine [91], curcumin [79], and resveratrol [78] (Table 1). 
Table 1. Studies regarding dietary compounds effects on cholesterol efflux capacity of HDL-C *

\begin{tabular}{|c|c|c|c|c|}
\hline Author, Year & $\begin{array}{c}\text { Dietary } \\
\text { Compounds }\end{array}$ & Dose/Time & $\begin{array}{c}\text { Study Design } \\
n\end{array}$ & $\begin{array}{l}\text { Main Results on Efflux } \\
\text { Capacity on HDL-C }\end{array}$ \\
\hline Hernáez, 2017 [27] & $\begin{array}{l}\text { TMD enriched with EVOO } \\
\text { TMD enriched with nuts } \\
\text { (walnuts, } \\
\text { hazelnuts, and } \\
\text { almonds) }\end{array}$ & $\begin{array}{c}1 \mathrm{~L} / \text { week } \\
30 \mathrm{~g} / \mathrm{d} \text { (15 g walnuts, } \\
7.5 \text { g hazelnuts, } \\
7.5 \text { g almonds) } \\
1 \text { year }\end{array}$ & $\begin{array}{c}\text { A randomized controlled trial } \\
\text { subsample PREDIMED study } \\
296 \text { subjects } \\
\text { (TMD-EVOO; } n=100 \text { and } \\
\text { TMD-Nuts; } n=100 \\
\text { low-fat control diet; } \\
n=96) .\end{array}$ & $\begin{array}{c}\uparrow \text { CEC TMD-EVOO interventions } \\
\text { relative to baseline } \\
(0.01 \pm 0.007 ; p=0.018) \\
\uparrow \text { CEC TMD-Nuts interventions } \\
\text { relative to baseline } \\
(0.02 \pm 0.09 ; p=0.013)\end{array}$ \\
\hline Hernáez, 2019 [81] & $\begin{array}{c}\text { EVOO } \\
\text { Whole grains }\end{array}$ & $\begin{array}{c}10 \mathrm{~g} / \mathrm{d} \text { (one spoonful) } \\
25 \mathrm{~g} / \mathrm{d} \\
1 \text { year }\end{array}$ & $\begin{array}{l}\text { A randomized controlled trial } \\
\text { subsample PREDIMED study } \\
296 \text { older adults' high } \\
\text { cardiovascular risk } \\
\text { (50-80 years) }\end{array}$ & $\begin{array}{c}\uparrow 0.7 \% \text { CEC }(0.08-1.2 ; p=0.026) \\
\text { with EVOO } \\
\uparrow 0.6 \% \text { CEC }(0.1-1.1 ; p=0.017) \text { with } \\
\text { whole grains. }\end{array}$ \\
\hline Fernández-Castillejo, 2017 [83] & $\begin{array}{l}\text { VOO (80 ppm) } \\
\text { FVOO enriched with its own PC } \\
(500 \mathrm{ppm}) \\
\text { FVOOT with its own PC plus thyme } \\
(500 \mathrm{ppm})\end{array}$ & $\begin{array}{c}25 \mathrm{~mL} / \text { day } \\
3 \text { weeks }\end{array}$ & $\begin{array}{c}\text { Crossover, double-blind, controlled } \\
\text { trial from the VOHF } \\
33 \text { hypercholesterolemic } \\
\text { subjects }\end{array}$ & $\begin{array}{c}\uparrow \text { CEC post-intervention vs. } \\
\text { pre-intervention values } \\
(4.1 \% \pm 1.4 ; p=0.042) . \\
\uparrow \text { HDL ApoA-I concentration } \\
(0.6 \pm 0.1 ; p=0.014) . \\
\text { Independent of VOO type. } \\
\text { CEC was related to concentration in } \\
\text { HDL of ApoA-I }(p=0.004) .\end{array}$ \\
\hline Farràs, 2017 [84] & $\begin{array}{l}\text { VOO (80 ppm) } \\
\text { FVOO enriched with its own PC } \\
(500 \text { ppm }) \\
\text { FVOOT with its own PC plus thyme } \\
(500 \text { ppm })\end{array}$ & $\begin{array}{c}25 \mathrm{~mL} / \text { day raw OO } \\
\text { (between meals) } \\
3 \text { weeks } \\
2 \text { weeks wash-out } \\
\text { periods }\end{array}$ & $\begin{array}{l}\text { Randomized, double-blind, } \\
\text { crossover, controlled trial from the } \\
\text { VOHF } \\
33 \text { hypercholesterolemic } \\
\text { subjects }\end{array}$ & $\begin{array}{c}\text { FVOOT versus FVOO intervention } \\
\uparrow \text { CEC }(1.3 \% \pm 3.9 \text { and } 1.2 \% \pm 3.8 \\
\text { respectively; } p=0.019) \\
\text { FVOOT versus VOO } \\
\downarrow(-0.03 \%+5.4) \\
\text { FVOOT post-intervention versus } \\
\text { baseline. } \\
\begin{array}{c}\uparrow \text { CEC }(29.7 \% \pm 5.6 \text { vs. } 28.3 \% \pm 6.7 \\
p=0.086)\end{array}\end{array}$ \\
\hline
\end{tabular}


Table 1. Cont.

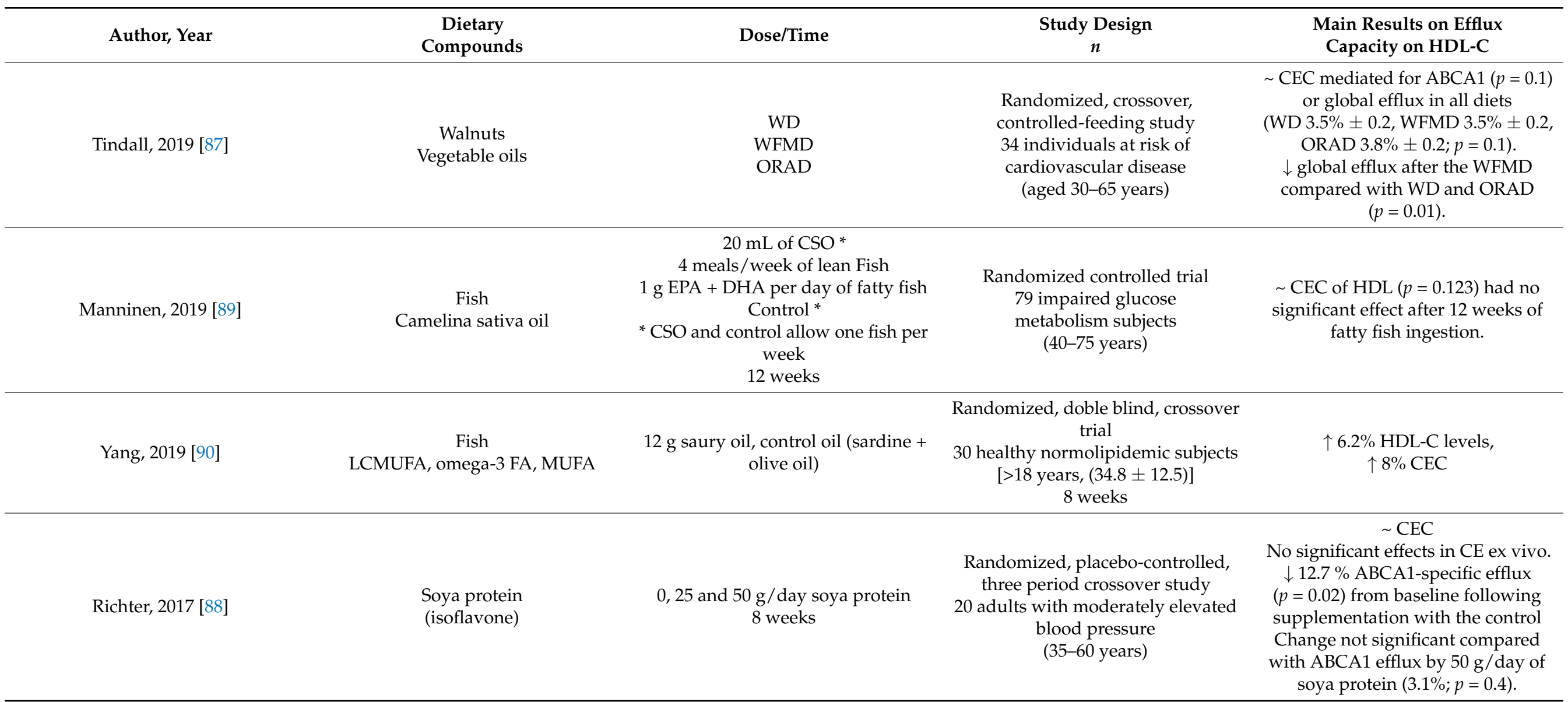


Table 1. Cont

\begin{tabular}{|c|c|c|c|c|}
\hline Author, Year & $\begin{array}{l}\text { Dietary } \\
\text { Compounds }\end{array}$ & Dose/Time & $\begin{array}{c}\text { Study Design } \\
n\end{array}$ & $\begin{array}{l}\text { Main Results on Efflux } \\
\text { Capacity on HDL-C }\end{array}$ \\
\hline Millar, 2018 [92] & Grape & $\begin{array}{c}60 \mathrm{~g} / \text { day of freeze-dried grape } \\
\text { powder (GRAPE, } 195 \mathrm{mg} \\
\text { polyphenols) } \\
60 \mathrm{~g} \text { / day of placebo } \\
\text { powder } \\
\text { (without polyphenols) } \\
4 \text { weeks } \\
3 \text { weeks washout }\end{array}$ & $\begin{array}{l}\text { Randomized, double-blind, } \\
\text { crossover placebo-controlled study } \\
20 \text { adults with MS } \\
\text { (aged } 32-70 \text { years) }\end{array}$ & $\begin{array}{c}\sim \text { CEC after interventions with } \\
\text { grape and placebo }(15.1 \% \pm 5.0 \text { and } \\
14.4 \pm 5.5 ; \text { respectively). } \\
\text { Grape not affect HDL CEC } \\
\text { compared with placebo } \\
(0.7 \pm 4.2 ; p=0.47)\end{array}$ \\
\hline Marín-Echeverri, 2018 [93] & Agraz (fruit) & $\begin{array}{l}200 \mathrm{~mL} \text { freeze-dried agraz } \\
\text { reconstituted/day } \\
\text { Placebo (similar beverage without } \\
\text { any polyphenols) } 12 \text { weeks }\end{array}$ & $\begin{array}{l}\text { Double-blind crossover study } \\
40 \text { women with MS }\end{array}$ & $\begin{array}{c}\sim \text { CEC }(0.5 \% \pm 2.9 ; p=0.324) \text { after } \\
\text { comparing the end of both } \\
\text { intervention periods } \\
\text { (placebo versus agraz) }\end{array}$ \\
\hline Talbot, 2018 [97] & $\begin{array}{c}\text { Cocoa } \\
\text { (theobromine) }\end{array}$ & $\begin{array}{l}20 \mathrm{~mL} \text { drink (500 mg of } \\
\text { theobromine) } \\
20 \mathrm{~mL} \text { placebo drink per day } \\
4 \text { weeks }\end{array}$ & $\begin{array}{l}\text { Randomized, double-blind, } \\
\text { controlled, crossover study } \\
44 \text { overweight and obese } \\
\text { subjects } \\
\text { (aged } 45-70 \text { years) }\end{array}$ & $\begin{array}{c}\text { Not affect fasting CEC after } \\
\text { theobromine intervention }(+0.4 \% \\
\text { point; }-2.81,3.57 ; p=0.81) . \\
\sim \text { CEC after theobromine on fasting } \\
\text { and postprandial CEC } \\
(97.5 \% \pm 9.2 \text { to } 99.1 \pm 11.7) .\end{array}$ \\
\hline Nicod, 2014 [91] & $\begin{array}{c}\text { Polyphenols } \\
\text { (red wine, cocoa, or green tea) }\end{array}$ & $\begin{array}{c}50 \mu \mathrm{M} \text { total polyphenols (gallic acid } \\
\text { equivalents) } \\
24 \mathrm{~h}\end{array}$ & $\begin{array}{l}\text { In vitro study Caco-2 monolayer } \\
\text { model }\end{array}$ & $\begin{array}{l}\text { No change of cholesterol efflux, via } \\
\text { SR-B1 (cholesterol is taken up by } \\
\text { SR-B1) }\end{array}$ \\
\hline
\end{tabular}


Table 1. Cont.

\begin{tabular}{|c|c|c|c|c|}
\hline Author, Year & $\begin{array}{l}\text { Dietary } \\
\text { Compounds }\end{array}$ & Dose/Time & $\begin{array}{c}\text { Study Design } \\
n\end{array}$ & $\begin{array}{l}\text { Main Results on Efflux } \\
\text { Capacity on HDL-C }\end{array}$ \\
\hline Voloshyna, 2013 [78] & Resveratrol & $\begin{array}{c}10,25 \mu \mathrm{M} \\
4 \mathrm{~h}(\mathrm{CEC} \text { of ApoA-1) } \\
6 \mathrm{~h}(\mathrm{CEC} \text { to HDL })\end{array}$ & $\begin{array}{c}\text { In vitro study TPH-1 monocytes } \\
\text { and macrophages, HAEC, PBMC, } \\
\text { HMDM } \\
18 \mathrm{~h}\end{array}$ & $\begin{array}{c}\uparrow A B C A 1 \text { message }(10 \mu \mathrm{M}) \text { in TPH1 } \\
\text { and HAEC vs. control }(168.2 \pm 13.3 \text {; } \\
141.3 \pm 15.4 \% ; p<0.001) \\
\uparrow A B C G 1 \text { expression in TPH-1 } \\
(169.9 \pm 15.1 \% ; p<0.001) \\
\uparrow L X R \alpha \text { mRNA }(10 \mu \mathrm{M}) \text { in TPH-1 } \\
\text { and HAEC vs. control } \\
(148.9 \pm 13.3 \% \text { vs. } 125.8 \pm 10.3 \% ; \\
p<0.05) \\
\uparrow 4.6 \% \text { CEC to ApoA- } 1 \text { in TPH-1 } \\
(20 \mu \mathrm{M} / \mathrm{mL}, 4 \text { h) vs. } 3.8 \% \text { control } \\
(p<0.05) . \\
\uparrow 136.2( \pm 8.5 \% ; p<0.001) \text { PPAR } \gamma \\
\text { expression vs. control }\end{array}$ \\
\hline Sun, 2015 [75] & Quercetin & $\begin{array}{c}0,25,50,100,200 \mu \mathrm{M} \\
0,4,8,16,24,32 \mathrm{~h}\end{array}$ & $\begin{array}{c}\text { In vitro study } \\
\text { TPH-1 derived foam cells }\end{array}$ & $\begin{array}{c}200 \mu \mathrm{M}, 32 \mathrm{~h} \\
\uparrow \text { ApoA-I dependent CEC after } \\
200 \mu \mathrm{M}, 32 \mathrm{~h} \text { vs. without treatment } \\
(>30 \% \text { vs. } 10 \% ; p<0.001) \\
\uparrow P P A R \gamma \text { expression and activation } \\
(p<0.001) \text { in } 200 \mu \mathrm{M}, 32 \mathrm{~h} .\end{array}$ \\
\hline
\end{tabular}


Table 1. Cont.

Author, Year
Quercetin

Dietary

Compounds
$12.5 \mathrm{mg} / \mathrm{Kg} / \mathrm{d}$ in $0.5 \% \mathrm{CMCNa}$

$2.5,5.0,10.0 \mu \mathrm{M}$

8 weeks

Dose/Time

Study Design

$n$

In vivo study

Experimental animal model

(apoE-deficient mice fed a high-fat

diet)

24 mice

CMCNa group $(n=12)$, quercetin group $(n=12)$

$12 \mathrm{~h}$

In vitro study

Murine macrophage RAW264.7 cell line and monocyte TPH-1 cell line

\section{Main Results on Efflux}

Capacity on HDL-C

$\uparrow 31.8 \%$ CEC from macrophages in

the quercetin-treated mice vs.

controls $(p<0.01)$

$\uparrow 22 \%$ HDL in quercetin group $(p<0.01)$

$\uparrow \mathrm{CEC}$ in a concentration-depend manner 5.0 and $10.0 \mu \mathrm{M}(p<0.01)$

$\uparrow \mathrm{CEC}$ in macrophage in a dose-dependent manner $(10,20$

$40 \mu \mathrm{M})$ vs. untreated group $(p<0.05)$.

$\uparrow A B C A 1$ and $S R B 1$ expression and protein level $(10,20,40 \mu \mathrm{M}) \mathrm{vs}$ control group $(p<0.05)$.

$\sim$ SRB1 expression.

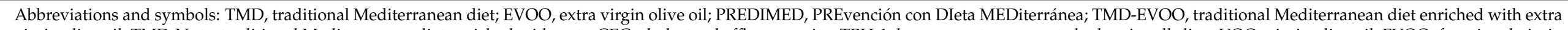

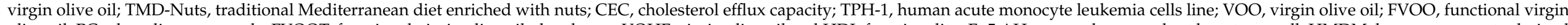

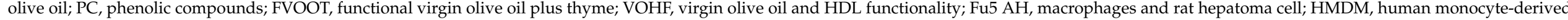

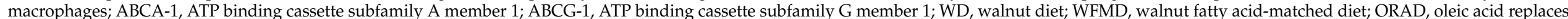

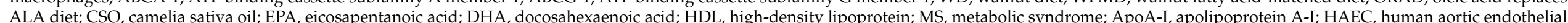

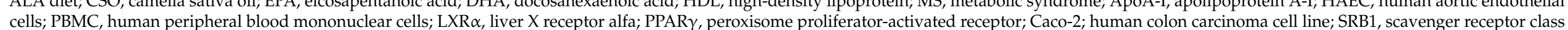

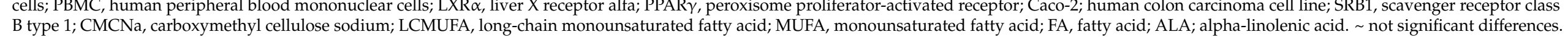
${ }^{*}$ In vitro studies were performed independent of the study design for the CEC assessment (different cell lines included). $\downarrow$ : decreasing; $\uparrow:$ increasing. 


\subsubsection{Extra Virgin Olive Oil}

It is the main component of the MD and is characterized by its nutritional composition, composed mainly of monounsaturated fatty acids (MUFAs), the majority being oleic acid and polyphenol compounds such as oleuropein and hydroxytyrosol $[105,106]$.

A randomized controlled trial with a subsample from the PREDIMED study $(n=296)$, the effects of two traditional Mediterranean diets (TMD) were compared to investigate the effects of extra virgin olive oil (EVOO) and nuts on different HDL functional properties. One group received a dietary intervention that was enriched with one liter of EVOO per week (TMD-EVOO; $n=100$ ). The other group received an additional $30 \mathrm{~g}$ of nuts per day (TMD-Nuts; $n=100$ ). Both these groups were compared to a low-fat control diet $(n=96)$. After a one-year intervention, CEC levels increased relative to baseline (unitless ratio; THP-1 macrophage based model) (mean 0.01 (SD 0.07; $p=0.018$ ); mean 0.02 (SD 0.09; $p=0.013$ ); Table 1) [27].

In another study 33 hypercholesterolemic participants were enrolled into a crossover, double-blind, controlled intervention: the Virgin Olive Oil and HDL functionality (VOHF) study. The study assessed the relationship between CEC and changes in HDL-related variables (composition, fluidity, oxidative/antioxidative status, and particle size) after participants consumed $25 \mathrm{~mL}$ /day of three types of virgin olive oil (VOO): VOO (control, $80 \mathrm{ppm}$ ), functional olive oil enriched with its own phenolic compounds (FOO1, $500 \mathrm{ppm}$ ), and functional olive oil enriched with its own phenolic compounds plus thyme (FOO2, $500 \mathrm{ppm}$ ). The study intervention was organized into three intervention periods of three weeks each and included a two-week washout period with refined olive oil. The results showed a significant increase in a range of measures after intervention compared to pre-intervention as it is shown in the following data: \% CEC (4.1(SD \pm 1.4$) ; p=0.042), \mathrm{HDL}$ ApoA-I concentration ( $0.6(\mathrm{SD} \pm 0.1) ; p=0.014)$, and antioxidants in HDL: $\alpha$-tocopherol (12.7 (SD \pm 0.7$) ; p=0.017), \beta$-cryptoxanthin $(8.7(\mathrm{SD} \pm 3.4) ; p<0.001)$, coenzyme-Q $(324.2$ (SD \pm 191.1$) ; p=0.005)$, and phenolic compounds (63.7 (25th-75th percentile 0-588.3); $p<0.001$ ). These results were independent of the type of $\mathrm{VOO}$ (natural VOO or enriched with phenolic compounds or thyme). CEC was inversely related with small HDL particles size $(\mathrm{r}=-0.3 ; p<0.001)$, but directly related to the concentration in HDL of ApoA-I $(p=0.004)$, esterified cholesterol $(\mathrm{r}=0.2 ; p=0.040)$, medium $(\mathrm{r}=0.2 ; p=0.012)$, and large $(\mathrm{r}=0.2 ; p=0.041)$ HDL particles (Figure 2) [83].

Recently, a before-after study with a subsample of 296 high cardiovascular risk older adults (50-80 years) from the PREDIMED trial aimed to determine whether the increase in the intake of cardioprotective food groups (EVOO, nuts (walnuts, almonds, pistachios, hazelnuts, and pine nuts), fruit and vegetables, legumes, whole grains, fish, and wine) for 1 year was linked to improvements in HDL functions. The results showed that after 1 year of daily consumption of a $10 \mathrm{~g}$ serving (one spoonful) of EVOO was independently associated with increases in the CEC of $0.7 \%(0.08-1.27 ; p=0.026)$ adjusted for age, sex, intervention group, clinical conditions, adherence to $\mathrm{MD}$, and physical activity. The consumption of $25 \mathrm{~g}$ of whole grains increased CEC by $0.6 \%(0.1-1.1 ; p=0.017)$, a similar protective effect to EVOO. However, the results could have been confounded by the high intake of dietary fiber and polyphenols [81].

Other results, in the same way, were observed by Farras et al. (2017). The consumption of phenol-enriched olive oils increased HDL-antioxidant compounds on a group of hypercholesterolemic adults. Cholesterol efflux raised $1.3 \%$ on the population of the intake olive oils high in polyphenols [84].

\subsubsection{Resveratrol}

Resveratrol is a polyphenol present in the skin of red grapes [107]. Several researchers have identified the cardioprotective effects of resveratrol [78,107]. A study in vitro explored its potential atheroprotective impact on CE in cells of the arterial wall, including human TPH-1 monocytes and macrophages, human peripheral blood mononuclear cells (PBMC), human monocyte-derived macrophages (HMDM), and human aortic endothelial cells 
(HAEC). Cells were incubated for $18 \mathrm{~h}$ under different experimental conditions including solvent control and resveratrol concentrations of $10 \mu \mathrm{M}$ and $25 \mu \mathrm{M}$. The main outcomes reported that the exposure of cells to $10 \mu \mathrm{M}$ of resveratrol increased ABCA-1 signaling in TPH-1 and HAEC vs. control (mean 168.2\% (SEM $\pm 13.3 \%$ ); mean $141.3 \%$ (SEM $\pm 15.4 \%$ ); $p<0.001)$, respectively. The authors express similar results were obtained in TPH-1 monocytes and PBMC. ABCG-1 upregulation was found in TPH-1 (mean 169.9(SEM $\pm 15.1 \%$ ); $p<0.001)$, contributing to promote $\mathrm{CE}$ to apoA-I $(20 \mu \mathrm{g} / \mathrm{mL}, 4 \mathrm{~h})$ in TPH-1 up to $4.6 \%$ compared to $3.8 \%$ of solvent control $(p<0.05)$. Expression of LXR $\alpha$ (mRNA) with a concentration of $10 \mu \mathrm{M}$ of resveratrol was increased in both TPH-1 macrophages and HAEC (mean $148.9 \%(\mathrm{SEM} \pm 13.3 \%)$ and (mean $125.8 \%$ (SEM $\pm 10.3 \%$ ) of control; $p<0.05)$, respectively. The incubation of cells with $25 \mu \mathrm{M}$ of resveratrol had an even greater effect on RCT protein expression in both cells. Just as in other studies, resveratrol regulates PPAR $\gamma$ expression versus control (mean 136.2\% (SEM $\pm 8.5 \%) ; p<0.001$ ) [78].

Despite this, some clinical trials have recently published the effects of resveratrol (variable doses) on different chronic conditions with high cardiovascular risk. None of them was aimed to explore the role of resveratrol on CEC, and some of these studies are mentioned in the following. In a randomized, double-blind controlled trial, 56 patients with T2DM or coronary heart disease were included. The intervention group received $500 \mathrm{mg}$ /day resveratrol during four weeks, and the metabolic status was investigated; the more related outcomes in relation to HDL were the increasing levels of HDL-C ( $\beta$ $3.38 \mathrm{mg} / \mathrm{dL} ; 95 \% \mathrm{CI}=1.72-5.05 ; p<0.001)$ and significantly decreasing total-/HDL$\mathrm{C}$ ratio $(\beta-0.36 ; 95 \% \mathrm{CI}=-0.59--0.13 ; p=0.002)$ [108]. The effect of resveratrol on anthropometric and biochemical parameters was assessed in subjects with BMI $>30 \mathrm{~kg} / \mathrm{m}^{2}$ who were supplemented with $250 \mathrm{mg}$ resveratrol/day, submitted physical activity and diet regulation for three months, and compared with a placebo group. This approach addressed to control metabolic syndrome components and found increasing levels of HDL-C $(p=0.026)$ compared to placebo [109]. The long-term effect of resveratrol has also been assessed in a randomized, double-blind, placebo-controlled trial. This study was oriented to determine the impact of high and low resveratrol treatments (1000 and $150 \mathrm{mg}$ resveratrol/day) on inflammation and metabolic syndrome. Unexpectedly resveratrol treatments did not improve the inflammatory status, nor did it change the HDL-C levels. High resveratrol doses increased total cholesterol $(p<0.002)$ and LDL levels $(p>0.006)$ compared to placebo [110].

\subsubsection{Nuts}

Nuts are rich in unsaturated fat (oleic acid), polyunsaturated fatty acids (linoleic acid and $\alpha$-linolenic acid), protein, dietary fiber, vitamins, and other bioactive compounds such as polyphenols [111].

Currently, other clinical trials have been performed to evaluate the intake of nuts and CEC. The objective was to examine the effect of replacing saturated fatty acids with unsaturated fats from walnuts or vegetable oils on lipoprotein subclasses, cholesterol efflux, and other markers. A randomized, crossover, controlled-feeding study was conducted with men and women (aged 30-65 years) with overweight and obesity, LDL-C between 121-177 mg/dL and/or elevated blood pressure (systolic: $120-159 \mathrm{mmHg}$; diastolic: $80-99 \mathrm{~mm} \mathrm{Hg}$ ), and free of chronic disease with no history of CVD. The authors compared the study variables on isocaloric diets: (1) rich in $\alpha$-linolenic acid from nonwalnut sources; (2) higher in monounsaturated fatty acid from oleic acid. There were no differences between diets for HDL-C or LDL-C subclasses. Cholesterol efflux capacity was unchanged after the diets [87].

\subsubsection{Legumes and Fish}

Legumes are a great source of vegetable protein, vitamins, minerals, fibers, antioxidants, and other bioactive compounds such as phytohemagglutinin (lectins), phytoestrogens, oligosaccharides, saponins, and phenolic compounds [112]. The main phenolic 
compounds of legumes are phenolic acids, flavonols, flavones, isoflavones, anthocyanins, and condensed tannins [113]. On the other hand, fish oil is characterized by its high omega 3 polyunsaturated fatty acids including eicosapentaenoic acid (EPA) and docosahexaenoic acid (DHA) content [107].

In the case of fish, two trials were designed to assess its consumption effect on the atherogenic and anti-atherogenic functions of LDL and HDL particles [89] and the response to saury oil over plasma lipids [90]. Both approaches considered the CEC as the major requisite for its inclusion as exemplars in Table 1. Seventy-nine subjects with impaired glucose metabolism (40-75 years) were recruited to participate for 12 weeks in a randomized-controlled trial. Subjects were randomly assigned to Camelina sativa oil (CSO), lean fish, fatty fish, or control group. Each group received an isocaloric diet. Fish diets included four meals per week (an estimate consumption of $1 \mathrm{~g}$ eicosapentanoic acid + docasahexaenoic acid), while the CSO group ingested $30 \mathrm{~mL}$ of CSO (an estimate of $10 \mathrm{~g}$ alpha-linolenic acid). CSO and control groups were allowed to eat fish once a week. HDL particles were isolated from the subjects before and after the 12 week intervention with fatty fish to determine the CEC, and no significant modification was observed [89]. In a double-blind, randomized crossover trial, 30 healthy normolipidemic subjects ( $>18$ years) were enrolled in an 8 week intervention study followed by 8 week washout lapse. Subjects were randomized to saury oil $(12 \mathrm{~g}=3.5 \mathrm{~g}$ long-chain monounsaturated fatty acid $+3.4 \mathrm{~g}$ omega-3 fatty acids) or control oil group (12 capsules $/$ day with sardine + olive oil $=4.9 \mathrm{~g}$ monounsaturated fatty acid $+3 \mathrm{~g}$ omega- 3 fatty acids). Both treatments had similar effects with respect to lowering plasma TG and VLDL levels (16\% and $25 \%$, respectively). It was an approximate $6 \%$ increment in HDL-C levels with both oils together with a $6 \%$ and $8 \%$ CEC rise, respectively (compared to baseline) [90].

One clinical trial was conducted to analyze the effect of a protein isolate (isoflavonecontaining soya) on HDL function, macrovascular function, and blood markers. This study enrolled 20 adults (35-60 years) with moderately elevated blood pressure $(129 / 82.5 \mathrm{mmHg}$, mean values). The subjects consumed 0,25 , and $50 \mathrm{~g}$ soy protein/day for 6 weeks with a 2 week washout period between treatments (three-period crossover). The soya protein isolate was obtained from soybean flakes with a content of $1.7 \mathrm{mg}$ of isoflavones per $\mathrm{g}$ of protein, which were formulated as protein powders. The participants incorporated the powders in their diet with no changes in dietary intake and physical activity. The $50 \mathrm{~g} / \mathrm{d}$ soya treatment reduced the systolic blood pressure compared to $25 \mathrm{~g} / \mathrm{d}(-2.3 \mathrm{mmHg}$, $p=0.03$ ) but not so for the control group. There were no changes in CEC, macrovascular function, or CVD markers. The authors point out the need for longer treatments and the assessment of equal production (soy metabolite) [88].

\subsubsection{Fruits}

A recently published Word Health Organization report recommends a minimum of $400 \mathrm{~g}$ of fruit and vegetables per day (excluding potatoes and other starchy tubers) for the prevention of cardiovascular diseases. The evidence about intake of fruit and HDL functions is developing.

Agraz is a fruit rich in polyphenols (mainly anthocyanins). A double-blind crossover study with 40 women (25-60 years) with metabolic syndrome was carried out to evaluate the effect of agraz consumption as compared to placebo on HDL function and inflammation. Women consumed agraz or placebo over 4 weeks with a period washout at the same duration. The main results observed were that, compared to placebo, agraz consumption did not significantly change any of biomarkers including HDL functionality [93].

Another fruit with high polyphenols is grapes. The authors evaluated the effects of grape powder ingestion on measures of HDL function in 20 adults (32-70 years, BMI $25.3-45.4 \mathrm{~kg} / \mathrm{m}^{2}$ ) with metabolic syndrome. The consumption of either $60 \mathrm{~g} / \mathrm{d}$ of freezedried grape powder or placebo for 4 weeks, separated by a 3 week washout period, was assessed in a randomized, double-blind crossover study. The intervention group did not show significant effects on cholesterol efflux capacity and other measures [92]. 


\subsubsection{Green Tea, Cocoa, and Red Wine}

They are considered foods rich in polyphenols [91] and have received special attention in cardiovascular risk prevention [91,114]. Green tea is characterized by its high levels of catechins, including epigallocatechin-gallate (EGCG), epigallocatechin (EGC), epicatechingallate (ECG), and epicatechin (EC) [114]. Similarly, the most abundant polyphenols in cocoa include catechins, anthocyanins, and proanthocyanins [115]. Red wine contains high concentrations of polyphenolic compounds such as resveratrol and flavonoids (catechin, epicatechin, quercetin, anthocyanin, and procyanidins) [116].

There is only one study that has investigated the association between polyphenols from green tea, cocoa, red wine, and CEC. This in vitro study used human colon carcinoma cell line (Caco-2) supplemented with a concentration of $50 \mu \mathrm{M}$ of total polyphenols (red wine, green tea, or cocoa extracts) calculated as gallic acid equivalents. The main aims were to assess the effect of polyphenols on intestinal inflammation, using Caco-2 monolayer model, and to investigate the action mechanisms of the increase in HDL-C by polyphenols. This study did not find any effect on cholesterol secretion or cholesterol uptake by SR-B1 or HDL functionality after $24 \mathrm{~h}$ with $50 \mu \mathrm{M}$ of total polyphenols. However, the study suggests that polyphenols from red wine and green tea could modulate intestinal inflammation by the reduction in basolateral IL-6 secretion by Caco- 2 cells grown on Transwells and LPS-treated $(p<0.05)$. Nevertheless, the authors concluded that the effects were moderate, and there was variability in the results of different experiments. Finally, red wine, cocoa, and green tea administered at a dietary dose did not increase cholesterol secretion by intestinal cells nor enhanced HDL functionality [91].

\subsubsection{Curcumin}

Curcumin is a bioactive polyphenol, a yellow pigment of Curcuma longa (turmeric), often used as a spice in India and traditional Chinese medicine $[79,117,118]$. It has been considered to have antioxidant, anti-inflammatory, anti-angiogenic, and anticancer properties $[117,118]$.

Few research studies have investigated the effects of curcumin on improving HDL functionality regardless of HDL-C concentration [117]. An in vitro study in RAW264.7 and TPH-1 macrophages explored the effect of different concentrations of curcumin $(10,20$, $40 \mu \mathrm{M})$ on CEC. The authors concluded that curcumin had a dose-dependent effect on cholesterol efflux, and the \%CEC was approximately duplicated in both cell lines $(p<0.05)$ compared to the control group. It was additionally observed that RAW264.7 and TPH-1derived macrophages treated with all the different concentrations of curcumin for $12 \mathrm{~h}$ increased $A B C A 1$ and $S R B 1$ expression and protein level vs. data in the control group $(p<0.05)$, which promoted cholesterol efflux [79].

\subsubsection{Quercetin}

Quercetin is part of a group that comprises over 4000 naturally available plant phenolic compounds and is considered a flavonol, a type of flavonoid [75,99]. Its main food sources are vegetables and fruits such as elderberries, red onions, white onions, cranberries, green hot pepper, and red apples, among other foods [99,119].

Molecular studies in cell culture treated with quercetin demonstrated that quercetin increased $C E$ from macrophages through the expression of $A B C A 1$ in a dose and timedependent manner [75]. An in vitro study used treated foam cells derived from oxLDLinduced TPH-1 cells with different doses of quercetin $(0,25,50,100,200 \mu \mathrm{M})$ and periods $(0,4,8,16,24,32 \mathrm{~h})$ to investigate the function of quercetin on $\mathrm{CE}$ from foam cells, $A B C A 1$ and PPAR $\gamma$ expression. The results indicated that higher doses and longer exposure to quercetin resulted in a greater increase in apoA-I-dependent CEC $((200 \mu \mathrm{M}, \sim 20 \%$ increase in CEC); (32 $\mathrm{h},>20 \%$ in CEC)) and induced $A B C A 1$ expression at mRNA and protein levels in THP-1-derived foam cells (200 $\mu \mathrm{M}, p<0.01 ; p<0.001)$, respectively. Quercetin increased the expression and activation of PPAR $\gamma$ (PPAR $\gamma$ mRNA and protein levels; $200 \mu \mathrm{M}, 32 \mathrm{~h}$, 
$p<0.001)$ by $\sim 3$ times in a dose- and time-dependent manner. PPAR $\gamma$ upregulates $A B C A 1$ expression [75].

In the same way, an in vivo study in a model of 24 apoE-deficient mice fed with a highfat diet was divided into two groups: carboxymethyl cellulose sodium by gavage (CMCNa) group $(n=12,0.5 \% \mathrm{CMCNa})$ and the quercetin group $(12.5 \mathrm{mg} / \mathrm{kg} / \mathrm{d}$ in $0.5 \% \mathrm{CMCNa}$ by gavage) to investigate whether quercetin improves RCT in an atherosclerosis model of "apoE-/- mice" and the underlying mechanism by molecular techniques. The outcomes showed that CEC from macrophage to plasma increased $31.8 \%$ and HDL $22.1 \%$ in the quercetin-treated mice compared with the controls $(p<0.01)$. The authors concluded that quercetin improved $\mathrm{CEC}$ by upregulating the protein expression of the main transporters in RCT, ABCA-1, and ABCG-1 at a concentration of $2.5 \mu \mathrm{M}$, and also by elevating the cholesterol-accepting ability of HDL and apoA-I via reduction in oxidation (Figure 2) [76].

\subsection{Activity of Cholesteryl Ester Transfer Protein (CETP)}

CETP is an enzyme that plays a major role in lipid metabolism. It participates in transferring cholesteryl esters (CE) from HDL particles to triglyceride-poor lipoproteins (and subsequently to the liver) [82]. CETP activity has been associated with some dietary compounds (Table 2) such as legumes, fresh fish [81], EVOO [27,81], curcumin, and ginger [80].

Table 2. Studies on dietary compounds effects on the activity of CETP of HDL-C.

\begin{tabular}{|c|c|c|c|c|}
\hline Author, Year & $\begin{array}{c}\text { Bioactive } \\
\text { Compounds }\end{array}$ & Dose/Time & $\begin{array}{c}\text { Study Design } \\
n\end{array}$ & $\begin{array}{c}\text { Main Results on CETP } \\
\text { Activity }\end{array}$ \\
\hline Hernáez, 2017 [27] & $\begin{array}{l}\text { TMD- EVOO } \\
\text { TMD- Nuts }\end{array}$ & $\begin{array}{l}1 \text { L/week } \\
1 \text { year }\end{array}$ & $\begin{array}{l}\text { Randomized controlled } \\
\text { trial subsample } \\
\text { PREDIMED study } \\
\text { 296 subjects } \\
\text { (TMD-VOO; } n=100 \\
\text { and TMD-Nuts; } n=100, \\
\text { low-fat control diet; } \\
\quad n=96 \text { ). }\end{array}$ & $\begin{array}{c}\downarrow \text { CETP activity after } \\
\text { TMD-EVOO intervention } \\
\text { to baseline } \\
(-0.039 ; p=0.008) .\end{array}$ \\
\hline Hernáez, 2019 [81] & $\begin{array}{l}\text { Legumes } \\
\text { Fresh fish }\end{array}$ & $\begin{array}{c}25 \mathrm{~g} / \mathrm{d} \\
\text { (2 servings } / \text { week) each } \\
\text { one } \\
1 \text { year }\end{array}$ & $\begin{array}{l}\text { Randomized controlled } \\
\text { trial subsample } \\
\text { PREDIMED study } \\
296 \text { older adults of high } \\
\text { cardiovascular risk } \\
\text { (50-80 years) }\end{array}$ & $\begin{array}{c}25 \text { g legumes } \\
\downarrow 4.8 \%(p=0.0028) \text { CETP } \\
\text { activity } \\
25 \mathrm{~g} \text { fish consumption } \\
\downarrow 2.3 \% \text { CEPT activity }\end{array}$ \\
\hline Elseweidy, 2015 [80] & $\begin{array}{l}\text { Curcuminoids and } \\
\text { ginger }\end{array}$ & $\begin{array}{c}50 \mathrm{mg} / \mathrm{kg} / \mathrm{d} \\
200 \mathrm{mg} / \mathrm{kg} / \mathrm{d} \\
6 \text { weeks }\end{array}$ & $\begin{array}{c}\text { In vivo Study } \\
\text { Experimental animal } \\
\text { model } \\
\text { (rabbit model) } \\
\text { Fed high-cholesterol } \\
\text { diet } \\
6 \text { weeks } \\
3 \text { groups: } \\
\text { 1.TGE }(n=6) \\
\text { 2. Curcuminoids }(n=6) \\
\text { 3. Placebo }(n=6)\end{array}$ & $\begin{array}{c}\downarrow \text { hepatic CETP mRNA } \\
\text { expression TGE, } \\
\text { curcuminoids vs. placebo } \\
(8.7 \pm 0.7 ; 8.4 \pm 0.5 \text { vs. } \\
11 \pm 0.5 ; p<0.001) ; \\
\text { respectively. } \\
\downarrow \text { plasma CETP } \\
(199 \mathrm{pg} / \mathrm{mL} \pm 4 ; 152 \pm 5 \\
\text { vs. } 315 \pm 12 ; p<0.001) ; \\
\text { respectively. } \\
\text { Ginger was more effective } \\
\text { in } \\
\downarrow \text { plasma CETP } \\
(152 \text { pg } / \text { mL } \pm 5 \text { vs. } \\
199 \pm 4 ; p<0.001) \text { than } \\
\text { curcuminoids. }\end{array}$ \\
\hline
\end{tabular}

Abbreviations and symbols: HPCOO, high polyphenol content olive oil; LPCOO, low polyphenol content olive oil; CETP, cholesterol ester transporter protein; SD, standard deviation; TMD-EVOO, traditional Mediterranean diet enriched with extra virgin olive oil; TMD-Nuts, traditional Mediterranean diet enriched with nuts; PREDIMED, PREvención con DIeta MEDiterránea; TGE, total ginger extract; mRNA, messenger RNA. $\downarrow$ : decreasing. 


\subsubsection{Extra Virgin Olive Oil}

The subsample from the PREDIMED clinical trial in 296 older adults compared three intervention groups to investigate its effects on improving HDL functionality: supplementation with one liter of EVOO per week (TMD-EVOO), $30 \mathrm{~g}$ of nuts per day (TMD-Nuts), and a control group with a low-fat diet. This research demonstrated that CETP activity decreased significantly after the TMD-EVOO intervention compared to baseline $(-0.039$; $p=0.008)$ [27].

\subsubsection{Legumes and Fresh Fish}

In a study subsample of 296 high cardiovascular risk older adults from the PREDIMED trial, researchers aimed to determine if the increases in the intake of EVOO, fruit, vegetables, legumes, whole grains, fish, and wine for 1 year were linked to improvements in HDL functionality including CETP activity. The study found an increase in legume intake ( $25 \mathrm{~g}$ per day, 2 servings per week) was associated with a $4.8 \%$ decrease in CETP activity ( $p=0.0028)$, and an increase in fish consumption ( $25 \mathrm{~g} / \mathrm{d}, 2$ servings per week) was linked to a $-1.6 \%$ decline in CETP activity $(p=0.021)$ after 1 year of intervention. Compared with fish subtypes, only fresh fatty fish consumption was related to a greater decrease in CETP activity $(-2.3 \% ; p=0.043)$. No significant results were found in HDL functionality with the fruits, vegetables, and wine intake [81].

\subsubsection{Curcumin and Ginger}

Curcumin and ginger are characterized by their anti-atherogenic properties. Elseweidy et al. [80] in their experimental animal model study used hypercholesterolemic rabbits. They compared the atheroprotective potentials of total ginger extract (TGE), or curcuminoids extracted from turmeric, on lipoprotein profile, CETP, hepatic cholesterol, inflammatory, and oxidation biomarkers. Rabbits $(n=6)$ fed on a high-cholesterol diet for 6 weeks received three types of intervention (TGE, curcuminoids, and placebo). It resulted in lower hepatic CETP mRNA expression (8.4(SD \pm 0.5$), 8.7(\mathrm{SD} \pm 0.7), 11(\mathrm{SD} \pm 0.5)$, respectively; $p<0.001)$ and plasma CETP (152(SD \pm 5$) \mathrm{pg} / \mathrm{mL}, 199$ (SD \pm 4$)$, vs. 315(SD \pm 12$)$, respectively; $p<0.001)$ compared with placebo. Ginger was more effective than curcuminoids at decreasing plasma CETP (152 pg/mL (SD \pm 5$)$ vs. $199(\mathrm{SD} \pm 4) ; p<0.001)$, but not at its gene expression (Table 2). Curcuminoids and TGE decreased hepatic cholesterol (mean $28 \mathrm{mg} / \mathrm{g}(\mathrm{SD} \pm 0.7) ; 21(\mathrm{SD} \pm 1)$ vs. 30 (SD \pm 0.1 ); respectively), LDL-C (mean $184 \mathrm{mg} / \mathrm{dL}$ $(\mathrm{SD} \pm 13) ; 119(\mathrm{SD} \pm 8)$ vs. $373(\mathrm{SD} \pm 52)$ ) and increased HDL-C (mean $36.8 \mathrm{mg} / \mathrm{dL}$ $(\mathrm{SD} \pm 3.4) ; 32.2(\mathrm{SD} \pm 4.8)$ vs. $17.6(\mathrm{SD} \pm 0.7) ; p<0.001)$ compared with placebo. The authors concluded that the effects of curcuminoids and ginger are mediated by different mechanisms. TGE presents better results on plasma lipids, RCT, cholesterol synthesis, and inflammatory status; curcuminoids showed better antioxidant activity [80].

\subsection{Antioxidant Capacity: PON1 Activity/Expression}

The PON is a group of three members (PON1-3) of antioxidant enzymes associated with apoA-I contained in HDL. PON1 and PON3 are associated with cardiovascular health benefits by promoting cholesterol efflux to HDL and preventing lipoprotein oxidation [85].

The consumption of olive oils [27,81,85], nuts, fruit and vegetables [92-95], legumes, and fish [81] are associated with PON1 activity or expression (Table 3). 
Table 3. Studies on dietary compounds effects on antioxidant capacity of HDL-C through PON1.

\begin{tabular}{|c|c|c|c|c|}
\hline Author, Year & $\begin{array}{l}\text { Bioactive } \\
\text { Compounds }\end{array}$ & Dose/Time & $\begin{array}{c}\text { Study Design } \\
n\end{array}$ & $\begin{array}{l}\text { Main Results on PON1 Activity/ } \\
\text { Expression }\end{array}$ \\
\hline Michaličková, 2019 [94] & $\begin{array}{l}\text { Polyphenol-enriched } \\
\text { tomato Juice }\end{array}$ & $\begin{array}{c}\text { IG: } 200 \mathrm{~g} \text { tomato fruit juice enriched } \\
\text { with } 1 \mathrm{~g} \text { of ethanolic extract or } \\
\text { whole tomato fruit } \\
\text { CG: } 200 \mathrm{~g} \text { tomato fruit juice } \\
4 \text { weeks }\end{array}$ & $\begin{array}{c}\text { Randomized controlled single-blind } \\
\text { study } \\
26 \text { subjects } \\
\text { (aged } 45-60 \text { years) with Stage } 1 \\
\text { Hypertension }\end{array}$ & $\begin{array}{l}\text { PON1 in both groups } \\
\text { No significative changes baseline and } 4 \text { weeks after } \\
\text { IG and CG [157 U/L (141-541)-172 U/L (157-447); } \\
413 \text { U/L (264-484)-405 U/L (294-514)]; } p=0.769\end{array}$ \\
\hline Lazavi, 2018 [95] & Barberry juice & $\begin{array}{l}\text { IG: } 200 \mathrm{~mL} / \mathrm{d} \text { of } \mathrm{BJ} \\
\text { CG: no intervention } \\
\quad 8 \text { weeks }\end{array}$ & $\begin{array}{l}\text { Randomized clinical trial } \\
41 \text { diabetic subjects } \\
\text { (aged } 30-75 \text { years) }\end{array}$ & $\begin{array}{l}\uparrow 56.0 \mathrm{mg} / \mathrm{dL} \text { PON1 concentrations }( \pm 68.29 ; \\
p=0.015) \text { for IG at the end of the trial. }\end{array}$ \\
\hline Millar, 2018 [92] & Grape & $\begin{array}{c}60 \mathrm{~g} / \mathrm{d} \text { of freeze-dried grape powder } \\
\text { (GRAPE, } 195 \mathrm{mg} \text { polyphenols) } \\
60 \mathrm{~g} / \mathrm{d} \text { of placebo powder (without } \\
\text { polyphenols) } \\
4 \text { weeks } \\
\text { 3 weeks washout }\end{array}$ & $\begin{array}{l}\text { Randomized, double-blind, } \\
\text { crossover placebo-controlled study } \\
20 \text { adults with MS } \\
\text { (aged } 32-70 \text { years) }\end{array}$ & $\begin{array}{c}\text { PON1 arylesterase and PON1 lactonase activities } \\
\text { after interventions with grape and placebo } \\
(84.5 \mathrm{kU} / \mathrm{L} \pm 17.4 \text { and } 86.3 \mathrm{kU} / \mathrm{L} \pm 16.2) \text { and } \\
(15.8 \mathrm{kU} / \mathrm{L} \pm 3.2 \text { and } 15.6 \mathrm{kU} / \mathrm{L} \pm 2.5 ; \text { respectively }) \\
\text { Grape not affect PON1 lactonase activity compared } \\
\text { with placebo } \\
(0.2 \mathrm{kU} / \mathrm{L} \pm 1.8 ; p=0.6) .\end{array}$ \\
\hline Tabatabaie, 2020 [98] & Resveratrol & $\begin{array}{c}2 \text { capsules (1000 mg) of resveratrol } \\
\text { per day } \\
2 \text { capsules of methylcellulose } \\
\text { (placebo) per day } \\
8 \text { weeks }\end{array}$ & $\begin{array}{l}\text { Randomized, double-blind } \\
\text { controlled trial } \\
71 \text { patients with type } 2 \text { diabetes } \\
\text { (aged 30-60 years) }\end{array}$ & $\begin{array}{c}\uparrow \text { PON1 activity after supplementation with } \\
\text { resveratrol } \\
(15.3 \mathrm{U} / \mathrm{L} \pm 13.9 ; \\
p<0.001) \text { and compared with placebo group } \\
\quad(p=0.04) \\
\text { Significantly after adjusting confounding variables } \\
(p<0.001) .\end{array}$ \\
\hline Marín-Echeverri, 2018 [93] & Agraz (fruit) & $\begin{array}{c}200 \mathrm{~mL} \text { freeze-dried agraz } \\
\text { reconstituted/day } \\
\text { Placebo (similar beverage without } \\
\text { any polyphenols) } \\
12 \text { weeks }\end{array}$ & $\begin{array}{l}\text { Double-blind crossover study } \\
40 \text { women with MS } \\
\text { (aged 25-60 years). }\end{array}$ & $\begin{array}{l}\sim \text { PON1 arylesterase and lactonase activities } \\
(-0.7 \mathrm{kU} / \mathrm{L} \pm 8.8, p=0.643 ; 0.2 \mathrm{kU} / \mathrm{L} \pm 1.6,0.862) \\
\text { after comparing the end of both intervention periods } \\
\text { (placebo versus agraz); respectively. }\end{array}$ \\
\hline Hernáez, 2017 [27] & $\begin{array}{l}\text { TMD- EVOO } \\
\text { TMD- Nuts }\end{array}$ & $\begin{array}{l}1 \mathrm{~L} / \text { week } \\
1 \text { year }\end{array}$ & $\begin{array}{l}\text { Randomized controlled trial } \\
\text { subsample PREDIMED Study } \\
296 \text { subjects (older adults) } \\
\text { TMD-EVOO TMD-Nuts } \\
\text { Low-fat control diet. }\end{array}$ & $\sim$ PON1 in both groups \\
\hline
\end{tabular}


Table 3. Cont.

\begin{tabular}{|c|c|c|c|c|}
\hline Author, Year & $\begin{array}{c}\text { Bioactive } \\
\text { Compounds }\end{array}$ & Dose/Time & $\begin{array}{c}\text { Study Design } \\
n\end{array}$ & $\begin{array}{l}\text { Main Results on PON1 Activity/ } \\
\text { Expression }\end{array}$ \\
\hline Hernáez, 2019 [81] & $\begin{array}{l}\text { EVOO } \\
\text { Nuts } \\
\text { Legumes } \\
\text { Fish }\end{array}$ & $\begin{array}{c}1 \mathrm{~L} / \text { week } \\
30 \mathrm{~g} \text { per day } \\
25 \mathrm{~g} \text { per day } \\
25 \mathrm{~g} \text { per day } \\
2 \text { servings/week each (one) } \\
1 \text { year }\end{array}$ & $\begin{array}{c}\text { Randomized controlled trial } \\
\text { PREDIMED Study } \\
296 \text { older adult high cardiovascular } \\
\text { risk } \\
\text { (aged } 50-80 \text { years) }\end{array}$ & $\begin{array}{l}\text { Nuts, legumes and fish } \\
\uparrow 12.2 \%, 11.7 \% \text { and } 3.9 \% \text { PON1 antioxidant activity } \\
(0.13-24.2 ; p<0.049 ; \\
0.44-22.8 ; p=0.043 ; 0.40-7.45 ; \\
p=0.030) ; \text { respectively. }\end{array}$ \\
\hline $\begin{array}{l}\text { Fernández-Castillejo, } \\
2017 \text { [85] }\end{array}$ & $\begin{array}{l}\text { First Study (acute intake) } \\
\text { FVOOT (different } \\
\text { concentrations) } \\
\text { Second Study } \\
\text { (sustained intake) } \\
\text { Olive oil PC } \\
\text { Thyme PC }\end{array}$ & $\begin{array}{c}30 \mathrm{~mL} \text { single dose } \\
\text { L-FVOO } 250 \mathrm{ppm} \\
\text { M-FVOO } 500 \mathrm{ppm} \\
\text { H-FVOO, } 750 \mathrm{ppm} \\
25 \mathrm{~mL} \text { per day } \\
\text { FVOO }(80 \mathrm{ppm})+\text { OO-PC control } \\
\text { FVOO (550 ppm) own PC } \\
\text { FVOOT (550 ppm) own PC (50\% } \\
\text { secoiridoid derivatives) } \\
\text { FVOOT plus thyme (50\%; } \\
\text { flavonoids, PC, and monoterpenes) }\end{array}$ & $\begin{array}{c}\text { Two randomized, } \\
\text { crossover-controlled trial } \\
12 \text { healthy subjects and } 33 \\
\text { hypercholesterolemic subjects; } \\
\text { respectively. } \\
\text { Single-dose and } 3 \text { weeks }\end{array}$ & $\begin{array}{c}\downarrow \text { PON1 protein after } 2 \mathrm{~h} \text { of } 30 \mathrm{~mL} \text { of L-FVOO and } \\
\text { M-FVOO } \\
(5.1-6.4 \% ; p<0.005) \\
\uparrow \text { PON1 raw activity at } 4 \mathrm{~h} \text { time point }(p<0.05) . \\
\downarrow 10.9-12.4 \% \text { PON1 protein levels after VOO and } \\
\text { FVOO }(p<0.05) \\
\uparrow 5.1 \% \text { PON3 protein levels and PON1 catalytic } \\
\text { activity }(p<0.05) \\
\text { Pon1 gene expression correlated with PPAR } \gamma \\
(\mathrm{r}=0.966 ; p=0.034) .\end{array}$ \\
\hline Balsan, 2019 [96] & $\begin{array}{l}\text { Green tea } \\
\text { Yerba mate }\end{array}$ & $\begin{array}{l}1000 \text { mL per day of: } \\
\text { GT } \\
\text { YM } \\
\text { AT (control) } \\
8 \text { weeks }\end{array}$ & $\begin{array}{l}\text { Randomized, controlled, clinical } \\
\text { trial } \\
142 \text { overweight or obesity and } \\
\text { dyslipidemia (aged 35-60 years) }\end{array}$ & $\begin{array}{l}\uparrow 9.7 \% \text { PON1 serum levels after YM intervention } \\
(2625 \mathrm{pg} / \mathrm{mL} \text { to } 2880 \mathrm{pg} / \mathrm{mL} \text {, change } 255 \mathrm{pg} / \mathrm{mL} ; \\
p=0.005) \text {. } \\
\sim \text { PON1 serum levels after green tea intervention } \\
(2899 \mathrm{pg} / \mathrm{mL} \text { to } 2745 \mathrm{pg} / \mathrm{mL} \text {, change }-154 \mathrm{pg} / \mathrm{mL} ; \\
p=0.154) .\end{array}$ \\
\hline
\end{tabular}

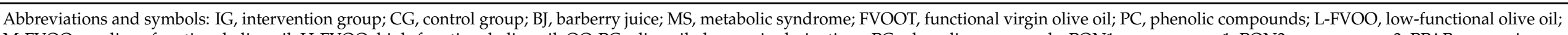

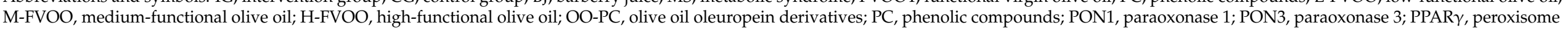

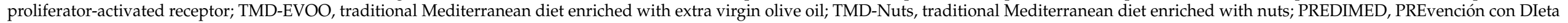
MEDiterránea Study; DP, dietary pattern; GT, green tea; YM, yerba mate; AT, apple tea. not significant differences. $\downarrow$ : decreasing; $\uparrow:$ increasing. 


\subsubsection{Olive Oil}

Two randomized, crossover-controlled trial interventions and an experimental design with rats were used by Fernández-Castillejo and colleagues [85]. The studies evaluated the short- and long-term modulation of acute and sustained intake of olive oils according to their PC content and source on PON-related variables and the mechanism involved in the OO-PC and thyme-PC effects on such variables. The mechanisms related to PON1 modulation were assessed with an experimental procedure.

In the first acute intake study, twelve healthy subjects were divided into three interventions with a single dose of $30 \mathrm{~mL}$ of functional virgin olive oil (FVOO) with different phenolic compounds (PC) content: low-FVOO (L-FVOO, 250 ppm), medium-FVOO (MFVOO, $500 \mathrm{ppm}$ ), high-FVOO (H-FVOO, $750 \mathrm{ppm}$ ). Blood samples were collected at baseline and 2, 4, and $6 \mathrm{~h}$ postprandial. It revealed that $30 \mathrm{~mL}$ of L-FVOO and M-FVOO decreased PON1 protein levels after $2 \mathrm{~h}$ of OO intake (5.1-6.4\%; $p<0.05)$, whereas H-FVOO promoted an increase in PON1 (6.8\%) at this time point vs. baseline without statistical significance. L-FVOO and M-FVOO intake increased paraoxonase raw activity at the $2 \mathrm{~h}$ time point followed by a decrease at $4 \mathrm{~h}$ time point $(p<0.05)$ [85].

The second study, a sustained intake study, was an intervention in 33 hypercholesterolemic volunteers, for three weeks with an intake of $25 \mathrm{~mL}$ per day of a control VOO and two different FVOO with the same PC content but differing in PC source: FVOO (80 ppm)+ olive oil oleuropein derivatives as hydroxytyrosol (OO-PC) as a control, $\mathrm{VOO}$ enriched with its own PCs (FVOO) (500 ppm, 50\% secoiridoid derivatives), and VOO enriched with its own PCs plus thyme (FVOOT) (50\% flavonoids, phenolic acids, and monoterpenes). It found that PC intake led to a decrease in PON1 protein levels by 10.9 and $12.4 \%$ after VOO and FVOO respectively, while it also increased the PON3 protein levels by $5.1 \%(p<0.05)$ and PON1 catalytic activity $(p<0.05)$. The mixture of OO-PC and FVOOT with thyme produced the opposite results [85].

The experimental design was a procedure with 20 male and female Wistar rats randomized into four groups: control diet (CD), CD supplemented with OO-PC extract (secoiridoids or hydroxytyrosol derivatives), diet supplemented with thyme phenol content extract (THY), and diet supplemented with secoiridoids and thyme extracts (SEC + THY). The rats ingested $5 \mathrm{mg}$ of phenolic extract $/ \mathrm{kg} / \mathrm{d}$ for 21 days. The results of the animal model showed that Pon1 gene expression was correlated with PPAR $\gamma(\mathrm{r}=0.966 ; p=0.034)$ and increased Pon3 hepatic gene expression in SEC group vs. CD group, while THY intake decreased Pon 1 and Pon 3 vs. SEC group. The authors suggested these changes in PON enzymes may reflect an improvement in HDL functionality as indicative of adequate oxidative balance [85].

In another crossover, double-blind, controlled trial which analyzed 33 hypercholesterolemic participants from VOHF after 3 weeks of intervention with different types of $\mathrm{VOO}$, the authors did not find a significant change in PON1 activity relative to baseline after one year of intervention with $\mathrm{VOO}(1 \mathrm{~L} /$ week) [83]. These results were confirmed in another study using a subsample of the PREDIMED trial where there was no significant change in PON1 arylesterase activity, after 1 year of intervention with TMD enriched with olive oil (1 L/week) [27].

\subsubsection{Fruits, Vegetables, and Resveratrol}

Four randomized controlled studies, three with a control group, were carried out to assess the intake of fruit ( 2 juice [94,95], 2 fruit freeze-dried [92,93]) on PON1 activity. The range time of the intervention was $4-12$ weeks. The participants were subjects with hypertension, diabetes, or metabolic syndrome (20-40 years). Three studies reported no significant changes between the intervention vs. the control group after the nutritional intervention, or at the end of the period intervention. Only Lazavi et al., 2018, showed that after 8 weeks of intake of barberry juice $(200 \mathrm{~mL})$ a significant increase in PON1 concentration $(56 \mathrm{mg} / \mathrm{dL} ; p=0.015)$ was seen compared with the control group [95]. 
The consumption of green tea or yerba mate has been evaluated on functions of HDL, in this case PON1 activity. A randomized clinical trial on 142 subjects with overweight or obesity and dyslipidemia determined PON1 activity on three intervention groups: intake $1000 \mathrm{~mL} / \mathrm{d}$ of green tea, $1000 \mathrm{~mL} / \mathrm{d}$ of yerba mate, or $1000 \mathrm{~mL} / \mathrm{d}$ apple tea. After 8 weeks of intervention, the authors observed a significant increase of $19.7 \%(p<0.05)$ PON1 serum concentration in the yerba mate group compared with the other groups. Green tea intervention group results were not changed [96].

One clinical trial with supplementation of resveratrol was found. Seventy-one patients with type 2 diabetes were randomized to intake $2000 \mathrm{mg}$ of resveratrol or placebo for 8 weeks, and PON1 activity was evaluated in blood. After this period of intervention, PON1 increased its activity significantly compared to the placebo group [98]. Data are not shown in the tables because the study did not evaluate the food intake.

\subsubsection{Nuts, Fish, and Legumes}

Nuts are rich in unsaturated fats (oleic acid), polyunsaturated fatty acids (linoleic acid and $\alpha$-linolenic acid), protein, dietary fiber, vitamins, and other bioactive compounds such as polyphenols [111].

A subsample of 296 high cardiovascular risk older adults from the PREDIMED clinical trial evaluated the intake of EVOO, nuts (walnuts, almonds, pistachios, hazelnuts, and pine nuts), fruit and vegetables, legumes, whole grains, fish, and wine on PON1 antioxidant activity. After 1 year, authors found improvements in PON1 antioxidant activity by $12.2 \%$ $(p=0.049), 11.7 \%(p=0.043)$, and $3.9 \%(p=0.030)$ after the consumption of $30 \mathrm{~g}$ of nuts per day (a small fistful), $25 \mathrm{~g}$ legumes per day ( 2 servings per week), and $25 \mathrm{~g}$ per day (2 servings per week) of fish, respectively [81].

\section{Conclusions}

The worldwide prevalence of low HDL-C among adults over 19 years is around $25 \%$, and it is a risk factor considered an important indicator to develop atherosclerosis. The number of people affected by dysfunctional HDL-C is still seldom studied.

There is not enough evidence at present about the association of HDL-C functionality and dietary compounds, and there are even fewer data regarding the suggested therapeutic doses of bioactive compounds to protect against cardiovascular diseases. More human studies are needed to investigate the effect of functional foods and their bioactive compounds on HDL alterations to develop nutritional precision recommendations for daily allowances to incorporate into the diet. Such evidence may be useful as part of a wider suite of prevention and management guidelines to reduce the global burden of cardiovascular disease.

In our review, we presented the studies available in the literature concerning three mechanisms of action of HDL-C, the anti-inflammatory HDL functions, and the evidence is even more limited. In summary, we found the following results for cholesterol efflux capacity: 3 randomized controlled trials, 3 randomized crossover-controlled trial, 2 randomized double-blind crossover-controlled trials, 1 randomized double-blind crossover trial, 1 crossover, double-blind, controlled trial, 1 double-blind crossover study, 4 in vitro, and 1 in vivo studies. The activity of cholesteryl ester transfer protein (CETP) included 2 randomized controlled trials and one in vivo study. Antioxidant capacity involving PON1 activity/expression included 3 randomized controlled trials, 1 randomized double-blind controlled trial, 1 randomized single-blind study, 1 randomized clinical trail, 1 randomized crossover-controlled trial, 1 randomized double-blind crossover-controlled trial, and 1 double-blind crossover trial. The critical examination of the trials published to date illustrates that intake of functional food and bioactive compounds leads to moderate or relevant improvements in HDL functions in high cardiovascular risk subjects. It is important to note that, in most of the analyzed clinical trials, the main objective was not to study HDL functionality, and the results were derived from sub-studies. 
Future scientific research has to strengthen the knowledge of the mechanisms between HDL-C and dietary compounds, as well as to the efficacy of functional foods and bioactive components in preventing or curtailing HDL dyslipidemia. It will involve the achievement of all types of basic and applied study designs, such as in vivo, in vitro, observational and clinical trials. Well-defined designs are needed with the specific proposals to the study HDL functions and concentrations, different populations with specific selection criteria, precise dose, and well-characterized bioactive components or food along with specific dietary patterns, planned endpoints, and several extended follow-ups. New research opportunities would include analysis of concentration and expression of HDL-C subfractions, HDL-LpPL-A2, and adhesion molecules linked with HDL-C. With this evidence collected, we can then reach the goals to have clinical and public health indicators of HDL-C functionality to prevent CVD, beyond just concentration.

Author Contributions: Conceptualization, K.P.L.-C. and F.M.-S.; writing—original draft preparation, K.P.L.-C.; writing - review and editing, K.P.L.-C., F.M.-S. and A.L.-Q.; critical revision of manuscript, A.L.-Q., S.L., J.F.M.-V. and B.V.; supervision, F.M.-S. and A.L.-Q. All authors have read and agreed to the published version of the manuscript.

Funding: This research was funded by the National Council of Science and Technology (Consejo Nacional de Ciencia y Tecnología, CONACYT) through doctoral scholarship from K.P.L.-C. (CVU number 954388) and Programa Nacional de Posgrados de Calidad (PNPC-CONACYT). K.P.L.-C. was benefited by 2019 Australia-Americas Ph.D. Research Internship Program. This program is funded in Australia by the Australian Government Department of Education and Training's Enabling Growth and Innovation Project Fund and is delivered by the Australian Academy of Science.

Data Availability Statement: No new data were created or analyzed in this study. Data sharing is not applicable to this article.

Acknowledgments: The figures were created with BioRender.com. We thank Ulises de la CruzMosso for initially reviewing the draft. We would like to do a special mention to Miguel Ángel Sigala, M.A, who was Vice Provost for International Affairs of the University of Guadalajara in 2019 and supported us to collaborate with Australian Universities.

Conflicts of Interest: The authors declare no conflict of interest.

\section{Abbreviations}

$\begin{array}{ll}\text { ABCA-1 } & \text { ATP-binding cassette transporter A member 1 } \\ \text { ABCG-1 } & \text { ATP-binding cassette transporter G member 1 } \\ \text { ABCG-4 } & \text { ATP-binding cassette transporter G member 4 } \\ \text { ACC/AHA } & \text { American College of Cardiology / American Heart Association } \\ \text { ApoA-I } & \text { Apolipoprotein A-I } \\ \text { Caco-2 } & \text { Human colon carcinoma cell line } \\ \text { CE } & \text { Cholesterol efflux } \\ \text { CEC } & \text { Cholesterol efflux capacity } \\ \text { CETP } & \text { Cholesteryl ester transfer protein } \\ \text { CMCNa } & \text { Carboxymethyl cellulose sodium } \\ \text { CVD } & \text { Cardiovascular diseases } \\ \text { DHA } & \text { Docosahexaenoic acid } \\ \text { EC } & \text { Epicatechin } \\ \text { ECG } & \text { Epicatechin-gallate } \\ \text { EGC } & \text { Epigallocatechin } \\ \text { EGCG } & \text { Epigallocatechin-gallate } \\ \text { EPA } & \text { Eicosapentaenoic acid } \\ \text { EVOO } & \text { Extra virgin olive oil } \\ \text { Fu5AH } & \text { Macrophages and rat hepatoma cell } \\ \text { FVOO } & \text { Functional virgin olive oil } \\ \text { H-FVOO } & \text { High- functional olive oil } \\ \text { HAEC } & \text { Human aortic endothelial cells }\end{array}$




\begin{tabular}{|c|c|}
\hline HDL-C & High-density lipoprotein cholesterol \\
\hline HMDM & Human monocyte-derived macrophage \\
\hline $\mathrm{HPCOO}$ & High polyphenol compound olive oil \\
\hline ICAM-1 & Intercellular adhesion molecule-1 \\
\hline IDL-C & Intermediate-density lipoprotein cholesterol \\
\hline IL-1 & Interleukin 1 \\
\hline IL-8 & Interleukin 8 \\
\hline L-FVOO & Low-functional olive oil \\
\hline LCAT & Lecithin cholesterol acyltransferase \\
\hline LDL-C & Low-density lipoprotein cholesterol \\
\hline $\mathrm{LPCOO}$ & Low polyphenol compound olive oil \\
\hline LPS & Lipopolysaccharides \\
\hline LXR & Liver $\mathrm{X}$ receptor \\
\hline $\mathrm{LXR}-\alpha$ & Liver $X$ receptor alfa \\
\hline M-CSF & Macrophage colony-stimulating factor \\
\hline M-FVOO & Medium-functional olive oil \\
\hline MCP-1 & Monocyte chemoattractant protein 1 \\
\hline MD & Mediterranean diet \\
\hline $\mathrm{MPO}$ & Myeloperoxidase \\
\hline MUFAs & Monounsaturated fatty acids \\
\hline NFk- $\beta$ & Factor kappa $\beta$ \\
\hline $\mathrm{NO}$ & Nitric oxide \\
\hline OO-PC & Olive Oil-Phenolic compounds \\
\hline ox-LDL & Oxidized LDL \\
\hline PAF-AH & Platelet-activating factor-acetylhydrolase \\
\hline PBMC & Human peripheral blood mononuclear cell \\
\hline PC & Phenolic compounds \\
\hline PON1 & Paraoxonase 1 \\
\hline PPARs & Peroxisome proliferation-activated receptors \\
\hline PREDIMED & PREvención con DIeta MEDiterránea \\
\hline PUFAs & Polyunsaturated fatty acids \\
\hline $\mathrm{RCT}$ & Reverse cholesterol transport \\
\hline ROS & Reactive oxygen species \\
\hline SAA & Serum amyloid A \\
\hline SEC + THY & Secoiridoid and thyme extracts \\
\hline SFA & Saturated fatty acids \\
\hline SMC & Smooth muscle cells \\
\hline sPLA2-IIA & Secretory phospholipase A2 \\
\hline SR-B1 & Scavenger receptor class B type 1 \\
\hline TGE & Total ginger extract \\
\hline THY & Thyme phenol content extract \\
\hline TLR & Toll-like receptors \\
\hline TMD & Traditional Mediterranean diet \\
\hline TNF & Tumor necrosis factor \\
\hline TPH-1 & Human acute monocyte leukemia cells line \\
\hline VCAM-1 & Vascular adhesion molecule-1 \\
\hline VD & Vegetarian diet \\
\hline VLDL-C & Very low-density lipoprotein cholesterol \\
\hline VOHF & Virgin olive oil and HDL functionality \\
\hline
\end{tabular}

\section{References}

1. Virani, S.S.; Alonso, A.; Benjamin, E.J.; Bittencourt, M.S.; Callaway, C.W.; Carson, A.P.; Chamberlain, A.M.; Chang, A.R.; Cheng, S.; Delling, F.N.; et al. Heart Disease and Stroke Statistics-2020 Update: A Report from the American Heart Association. Circulation 2020, E139-E596. [CrossRef] 
2. GBD Compare. Institute for Health Metrics and Evaluation (IHME). Available online: https://vizhub.healthdata.org/gbdcompare/ (accessed on 4 January 2021).

3. LatinComm, S.A. Manual para la Reducción del Riesgo Cardiovascular: Basado en las Guías del National Cholesterol Educaction Program Adult Treatment Panel III (NCEP-ATPIII); LatinComm: Buenos Aires, Argentina, 2011; pp. 2-28.

4. Rye, K.A.; Ong, K.L. HDL Function as a Predictor of Coronary Heart Disease Events: Time to Re-Assess the HDL Hypothesis? Lancet Diabetes Endocrinol. 2015, 3, 488-489. [CrossRef]

5. Mahmooda, S.S.; Levy, D.; Vasan, R.S.; Wang, T.J. The Framingham Heart Study and the Epidemiology of Cardiovascular Diseases: A Historical Perspective. Lancet 2014, 383, 1933-1945. [CrossRef]

6. Ouimet, M.; Barrett, T.J.; Fisher, E.A. HDL and Reverse Cholesterol Transport: Basic Mechanisms and Their Roles in Vascular Health and Disease. Circ. Res. 2019, 124, 1505-1518. [CrossRef] [PubMed]

7. Qiu, C.; Zhao, X.; Zhou, Q.; Zhang, Z. High-Density Lipoprotein Cholesterol Efflux Capacity Is Inversely Associated with Cardiovascular Risk: A Systematic Review and Meta-Analysis. Lipids Health Dis. 2017, 16. [CrossRef] [PubMed]

8. Carroll, M.D.; Fryar, C.D.; Nguyen, D.T. Total and High-Density Lipoprotein Cholesterol in Adults: United States, $2015-2018$. NCHS Data Brief. 2020, 363, 1-8.

9. Halcox, J.P.; Banegas, J.R.; Roy, C.; Dallongeville, J.; De Backer, G.; Guallar, E.; Perk, J.; Hajage, D.; Henriksson, K.M.; Borghi, C. Prevalence and Treatment of Atherogenic Dyslipidemia in the Primary Prevention of Cardiovascular Disease in Europe: EURIKA, a Cross-Sectional Observational Study. BMC Cardiovasc. Disord. 2017, 17, 1-11. [CrossRef] [PubMed]

10. Zhang, M.; Deng, Q.; Wang, L.; Huang, Z.; Zhou, M.; Li, Y.; Zhao, Z.; Zhang, Y.; Wang, L. Prevalence of Dyslipidemia and Achievement of Low-Density Lipoprotein Cholesterol Targets in Chinese Adults: A Nationally Representative Survey of 163,641 Adults. Int. J. Cardiol. 2018, 260, 196-203. [CrossRef] [PubMed]

11. Noubiap, J.J.; Bigna, J.J.; Nansseu, J.R.; Nyaga, U.F.; Balti, E.V.; Echouffo-Tcheugui, J.B.; Kengne, A.P. Prevalence of Dyslipidaemia among Adults in Africa: A Systematic Review and Meta-Analysis. Lancet Glob. Health 2018, 6, e998-e1007. [CrossRef]

12. Vizmanos, B.; Betancourt-Nuñez, A.; Márquez-Sandoval, F.; González-Zapata, L.I.; Monsalve-Álvarez, J.; Bressan, J.; De Carvalho Vidigal, F.; Figueredo, R.; López, L.B.; Babio, N.; et al. Metabolic Syndrome among Young Health Professionals in the Multicenter Latin America Metabolic Syndrome Study. Metab. Syndr. Relat. Disord. 2020, 18, 86-95. [CrossRef] [PubMed]

13. Kosmas, C.E.; Martinez, I.; Sourlas, A.; Bouza, K.V.; Campos, F.N.; Torres, V.; Montan, P.D.; Guzman, E. High-Density Lipoprotein (HDL) Functionality and Its Relevance to Atherosclerotic Cardiovascular Disease. Drugs Context 2018, 7, 1-9. [CrossRef]

14. O’Neill, F.; Riwanto, M.; Charakida, M.; Colin, S.; Manz, J.; McLoughlin, E.; Khan, T.; Klein, N.; Kay, C.W.M.; Patel, K.; et al. Structural and Functional Changes in HDL with Low Grade and Chronic Inflammation. Int. J. Cardiol. 2015, 188, 111-116. [CrossRef]

15. Rosenson, R.S.; Brewer, H.B.; Ansell, B.; Barter, P.; Chapman, M.J.; Heinecke, J.W.; Kontush, A.; Tall, A.R.; Webb, N.R. Translation of High-Density Lipoprotein Function into Clinical Practice: Current Prospects and Future Challenges. Circulation 2013, 128, 1256-1267. [CrossRef]

16. Feldman, F.; Koudoufio, M.; Desjardins, Y.; Spahis, S.; Delvin, E.; Levy, E. Efficacy of Polyphenols in the Management of Dyslipidemia: A Focus on Clinical Studies. Nutrients 2021, 13, 672. [CrossRef]

17. Hu, J.; Xi, D.; Zhao, J.; Luo, T.; Liu, J.; Lu, H.; Li, M.; Xiong, H.; Guo, Z. High-Density Lipoprotein and Inflammation and Its Significance to Atherosclerosis. Am. J. Med. Sci. 2016, 352, 408-415. [CrossRef]

18. Kontush, A.; Chapman, M.J. Functionally Defective High-Density Lipoprotein: A New Therapeutic Target at the Crossroads of Dyslipidemia, Inflammation, and Atherosclerosis. Pharmacol. Rev. 2006, 58, 342-374. [CrossRef] [PubMed]

19. Rosenson, R.S.; Brewer, H.B.; Ansell, B.J.; Barter, P.; Chapman, M.J.; Heinecke, J.W.; Kontush, A.; Tall, A.R.; Webb, N.R. Dysfunctional HDL and Atherosclerotic Cardiovascular Disease. Nat. Rev. Cardiol. 2016, 13, 48-60. [CrossRef] [PubMed]

20. Van Lenten, B.J.; Reddy, S.T.; Navab, M.; Fogelman, A.M. Understanding Changes in High Density Lipoproteins during the Acute Phase Response. Arterioscler. Thromb. Vasc. Biol. 2006, 26, 1687-1688. [CrossRef] [PubMed]

21. Hedrick, C.C.; Thorpe, S.R.; Fu, M.X.; Harper, C.M.; Yoo, J.; Kim, S.M.; Wong, H.; Peters, A.L. Glycation Impairs High-Density Lipoprotein Function. Diabetologia 2000, 43, 312-320. [CrossRef]

22. Woudberg, N.J.; Goedecke, J.H.; Blackhurst, D.; Frias, M.; James, R.; Opie, L.H.; Lecour, S. Association between Ethnicity and Obesity with High-Density Lipoprotein (HDL) Function and Subclass Distribution. Lipids Health Dis. 2016, 15, 1-11. [CrossRef]

23. Nicholls, S.J.; Lundman, P.; Harmer, J.A.; Cutri, B.; Griffiths, K.A.; Rye, K.A.; Barter, P.J.; Celermajer, D.S. Consumption of Saturated Fat Impairs the Anti-Inflammatory Properties of High-Density Lipoproteins and Endothelial Function. J. Am. Coll. Cardiol. 2006, 48, 715-720. [CrossRef] [PubMed]

24. Salazar, J.; Olivar, L.C.; Ramos, E.; Chávez-Castillo, M.; Rojas, J.; Bermúdez, V. Dysfunctional High-Density Lipoprotein: An Innovative Target for Proteomics and Lipidomics. Cholesterol 2015, 2015. [CrossRef] [PubMed]

25. Blazek, A.; Rutsky, J.; Osei, K.; Maiseyeu, A.; Rajagopalan, S. Exercise-Mediated Changes in High-Density Lipoprotein: Impact on Form and Function. Am. Heart J. 2013, 166, 392-400. [CrossRef] [PubMed]

26. Kraus, W.E.; Houmard, J.A.; Duscha, B.D.; Knetzger, K.J.; Wharton, M.B.; Mccartney, J.S.; Bales, C.W.; Henes, S.; Samsa, G.P.; Otvos, J.D.; et al. Effects of the Amount and Intensity of Exercise on Plasma Lipoproteins. N. Engl. J. Med. 2002, 347, 1483-1492. [CrossRef] 
27. Hernáez, Á.; Castañer, O.; Elosua, R.; Pintó, X.; Estruch, R.; Salas-Salvadó, J.; Corella, D.; Arós, F.; Serra-Majem, L.; Fiol, M.; et al. Mediterranean Diet Improves High-Density Lipoprotein Function in High-Cardiovascular-Risk Individuals. Circulation 2017, 135, 633-643. [CrossRef]

28. Marques, L.R.; Diniz, T.A.; Antunes, B.M.; Rossi, F.E.; Caperuto, E.C.; Lira, F.S.; Gonçalves, D.C. Reverse Cholesterol Transport: Molecular Mechanisms and the Non-Medical Approach to Enhance HDL Cholesterol. Front. Physiol. 2018, 9, 1-11. [CrossRef]

29. Bardagjy, A.S.; Steinberg, F.M. Relationship between HDL Functional Characteristics and Cardiovascular Health and Potential Impact of Dietary Patterns: A Narrative Review. Nutrients 2019, 11, 1231. [CrossRef]

30. Siri-Tarino, P.W. Effects of Diet on High-Density Lipoprotein Cholesterol. Curr. Atheroscler. Rep. 2011, 13, 453-460. [CrossRef]

31. Arnett, D.K.; Blumenthal, R.S.; Albert, M.A.; Buroker, A.B.; Goldberger, Z.D.; Hahn, E.J.; Himmelfarb, C.D.; Khera, A.; LloydJones, D.; McEvoy, J.W.; et al. 2019 ACC/AHA Guideline on the Primary Prevention of Cardiovascular Disease: A Report of the American College of Cardiology/American Heart Association Task Force on Clinical Practice Guidelines. Circulation 2019, 140, 596-646. [CrossRef]

32. Mach, F.; Baigent, C.; Catapano, A.L.; Koskinas, K.C.; Casula, M.; Badimon, L.; Chapman, M.J.; De Backer, G.G.; Delgado, V.; Ference, B.A.; et al. 2019 ESC/EAS Guidelines for the Management of Dyslipidaemias: Lipid Modification to Reduce Cardiovascular Risk. Eur. Heart J. 2020, 41, 111-188. [CrossRef]

33. Raygor, V.; Khera, A. New Recommendations and Revised Concepts in Recent Guidelines on the Management of Dyslipidemias to Prevent Cardiovascular Disease: The 2018 ACC/AHA and 2019 ESC/EAS Guidelines. Curr. Cardiol. Rep. 2020, 22. [CrossRef]

34. Schaftenaar, F.; Frodermann, V.; Kuiper, J.; Lutgens, E. Atherosclerosis: The Interplay between Lipids and Immune Cells. Curr. Opin. Lipidol. 2016, 27, 209-215. [CrossRef]

35. Torres, N.; Guevara-Cruz, M.; Velázquez-Villegas, L.A.; Tovar, A.R. Nutrition and Atherosclerosis. Arch. Med. Res. 2015, 46, 408-426. [CrossRef]

36. Bergheanu, S.C.; Bodde, M.C.; Jukema, J.W. Pathophysiology and Treatment of Atherosclerosis: Current View and Future Perspective on Lipoprotein Modification Treatment. Neth. Heart J. 2017, 25, 231-242. [CrossRef] [PubMed]

37. Olvera-López, E. Cardiovascular Disease. Available online: https:/ /www.ncbi.nlm.nih.gov/books/NBK535419/ (accessed on 20 May 2020).

38. Rafieian-Kopaei, M.; Setorki, M.; Doudi, M. Atherosclerosis: Process, Indicators, Risk Factors and New Hope. Int. J. Med. 2014, 5, 927-946.

39. Mahan, L.K.; Escott-Stump, S.; Raymond, J. Krause Dietoterapia, 14th ed.; Elsevier: Barcelona, Spain, 2017.

40. Libby, P.; Buring, J.E.; Badimon, L.; Hansson, G.K.; Deanfield, J.; Bittencourt, M.S.; Tokgözoğlu, L.; Lewis, E.F. Atherosclerosis. Nat. Rev. Dis. Prim. 2019, 5, 1-18. [CrossRef] [PubMed]

41. Moss, J.W.E.; Ramji, D.P. Nutraceutical Therapies for Atherosclerosis. Nat. Rev. Cardiol. 2016, 13, 513-532. [CrossRef] [PubMed]

42. Shao, D.; Lian, Z.; Di, Y.; Zhang, L.; Shahid Riaz Rajoka, M.; Zhang, Y.; Kong, J.; Jiang, C.; Shi, J. Dietary Compounds Have Potential in Controlling Atherosclerosis by Modulating Macrophage Cholesterol Metabolism and Inflammation via MiRNA. NPJ Sci. Food 2018, 2, 1-9. [CrossRef]

43. Shao, B.; Tang, C.; Sinha, A.; Mayer, P.S.; Davenport, G.D.; Brot, N.; Oda, M.N.; Zhao, X.-Q.; Heineck, J.W. Humans with Atherosclerosis Have Impaired ABCA1 Cholesterol Efflux and Enchanced HDL Oxidation by Myeloperoxidase. Circ. Res. 2014, 23, 1733-1742. [CrossRef]

44. Pirillo, A.; Catapano-Alberico, L.; Norata-Giuseppe, D. Biologial Consequences of Dysfuncional HDL. Curr. Med. Chem. 2019, 26, 1644-1664. [CrossRef]

45. Iqbal, F.; Baker, W.S.; Khan, M.I.; Thukuntla, S.; McKinney, K.H.; Abate, N.; Tuvdendorj, D. Current and Future Therapies for Addressing the Effects of Inflammation on HDL Cholesterol Metabolism. Br. J. Pharmacol. 2017, 174, 3986-4006. [CrossRef] [PubMed]

46. Podrez, E.A. Anti-Oxidant Properties of High-Density Lipoprotein and Atherosclerosis. Clin. Exp. Pharmacol. Physiol. 2010, 37, 719-725. [CrossRef] [PubMed]

47. Ohashi, R.; Mu, H.; Wang, X.; Yao, Q.; Chen, C. Reverse Cholesterol Transport and Cholesterol Efflux in Atherosclerosis. QJM Mon. J. Assoc. Physicians 2005, 98, 845-856. [CrossRef] [PubMed]

48. Lee-Rueckert, M.; Escola-Gil, J.C.; Kovanen, P.T. HDL Functionality in Reverse Cholesterol Transport-Challenges in Translating Data Emerging from Mouse Models to Human Disease. Biochim. Biophys. Acta Mol. Cell Biol. Lipids 2016, 1861, 566-583. [CrossRef]

49. Joy, T.; Hegele, R.A. Is Raising HDL a Futile Strategy for Atheroprotection? Nat. Rev. Drug Discov. 2008, 7, 143-155. [CrossRef] [PubMed]

50. Rohatgi, A.; Khera, A.; Berry, J.D.; Givens, E.G.; Ayers, C.R.; Wedin, K.E.; Neeland, I.J.; Yuhanna, I.S.; Rader, D.R.; De Lemos, J.A.; et al. HDL Cholesterol Efflux Capacity and Incident Cardiovascular Events. N. Engl. J. Med. 2014, 371, 2383-2393. [CrossRef]

51. Yokoyama, S. ABCA1 and Biogenesis of HDL. J. Atheroscler. Thromb. 2006, 13, 1-15. [CrossRef]

52. Mineo, C.; Deguchi, H.; Griffin, J.H.; Shaul, P.W. Endothelial and Antithrombotic Actions of HDL. Circ. Res. 2006, 98, 1352-1364. [CrossRef] [PubMed]

53. Rozenberg, O.; Shih, D.M.; Aviram, M. Paraoxonase 1 (PON1) Attenuates Macrophage Oxidative Status: Studies in PON1 Transfected Cells and in PON1 Transgenic Mice. Atherosclerosis 2005, 181, 9-18. [CrossRef]

54. Ben-Aicha, S.; Badimon, L.; Vilahur, G. Advances in HDL: Much More than Lipid Transporters. Int. J. Mol. Sci. 2020, $21,732$. [CrossRef] 
55. Ahmed, Z.; Ravandi, A.; Maguire, G.F.; Emili, A.; Draganov, D.; La Du, B.N.; Kuksis, A.; Connelly, P.W. Apolipoprotein A-I Promotes the Formation of Phosphatidylcholine Core Aldehydes That Are Hydrolyzed by Paraoxonase (PON-1) during High Density Lipoprotein Oxidation with a Peroxvnitrite Donor. J. Biol. Chem. 2001, 276, 24473-24481. [CrossRef] [PubMed]

56. Baker, P.W.; Rye, K.A.; Gamble, J.R.; Vadas, M.A.; Barter, P.J. Ability of Reconstituted High Density Lipoproteins to Inhibit Cytokine- Induced Expression of Vascular Cell Adhesion Molecule-1 in Human Umbilical Vein Endothelial Cells. J. Lipid Res. 1999, 40, 345-353. [CrossRef]

57. Estrada-Luna, D.; Ortiz-Rodríguez, M.A.; Medina-Briseño, L.; Carreon-Torres, E.; Izquierdo-Vega, J.A.; Sharma, A.; Cancino-Díaz, J.C.; Pérez-Méndez, O.; Belefant-Miller, H.; Betanzos-Cabrera, G. Current Therapies Focused on High-Density Lipoproteins Associated with Cardiovascular Disease. Molecules 2018, 23, 2730. [CrossRef] [PubMed]

58. Hyka, N.; Dayer, J.M.; Modoux, C.; Kohno, T.; Edwards, C.K.; Roux-Lombard, P.; Burger, D. Apolipoprotein A-I Inhibits the Production of Interleukin-1 $\beta$ and Tumor Necrosis Factor- $\alpha$ by Blocking Contact-Mediated Activation of Monocytes by $\mathrm{T}$ Lymphocytes. Blood 2001, 97, 2381-2389. [CrossRef]

59. Chyu, K.Y.; Shah, P.K. HDL/ApoA-1 Infusion and ApoA-1 Gene Therapy in Atherosclerosis. Front. Pharmacol. 2015, 6, 187. [CrossRef]

60. Rallidis, L.S.; Tellis, C.C.; Lekakis, J.; Rizos, I.; Varounis, C.; Charalampopoulos, A.; Zolindaki, M.; Dagres, N.; Anastasiou-Nana, M.; Tselepis, A.D. Lipoprotein-Associated Phospholipase A2 Bound on High-Density Lipoprotein Is Associated with Lower Risk for Cardiac Death in Stable Coronary Artery Disease Patients: A 3-Year Follow-Up. J. Am. Coll. Cardiol. 2012, 60, 2053-2060. [CrossRef]

61. Huang, F.; Wang, K.; Shen, J. Lipoprotein-Associated Phospholipase A2: The Story Continues. Med. Res. Rev. 2020, 40, 79-134. [CrossRef]

62. Kontush, A.; Lindahl, M.; Lhomme, M.; Calabresi, L.; Chapman, M.; Davidson, J.W.S. High Density Lipoproteins: From Biological Understanding to Clinical Exploitation; Eckardstein, A., von Kardassis, D., Eds.; Springer: Paris, France, 2015; Volume 224, ISBN 9783319096650.

63. Murphy, A.J. High Density Lipoprotein: Assembly, Structure, Cargo, and Functions. ISRN Physiol. 2013, 2013, 186365. [CrossRef]

64. Femlak, M.; Gluba-Brzózka, A.; Ciałkowska-Rysz, A.; Rysz, J. The Role and Function of HDL in Patients with Diabetes Mellitus and the Related Cardiovascular Risk. Lipids Health Dis. 2017, 16, 1-9. [CrossRef]

65. Khera, A.V.; Rader, D.J. Future Therapeutic Directions in Reverse Cholesterol Transport. Curr. Atheroscler. Rep. $2010,12,73-81$. [CrossRef]

66. Ng, D.S.; Wong, N.C.W.; Hegele, R.A. HDL-Is It Too Big to Fail? Nat. Rev. Endocrinol. 2013, 9, 308-312. [CrossRef] [PubMed]

67. Van Horn, L.; Carson, J.A.S.; Appel, L.; Burke, L.E.; Economos, C.; Karmally, W. Recommended Dietary Pattern to Achieve Adherence to the American Heart Association/American College of Cardiology (AHA/ACC) Guidelines: A Scientific Statement From the American Heart Association. Circulation 2016, 134, e534. [CrossRef] [PubMed]

68. Domingo-Espín, J.; Nilsson, O.; Bernfur, K.; Del Giudice, R.; Lagerstedt, J.O. Site-Specific Glycations of Apolipoprotein A-I Lead to Differentiated Functional Effects on Lipid-Binding and on Glucose Metabolism. Biochim. Biophys. Acta Mol. Basis Dis. 2018, 1864, 2822-2834. [CrossRef] [PubMed]

69. Nobecourt, E.; Davies, M.J.; Brown, B.E.; Curtiss, L.K.; Bonnet, D.J.; Charlton, F.; Januszewski, A.S.; Jenkins, A.J.; Barter, P.J.; Rye, K.A. The Impact of Glycation on Apolipoprotein A-I Structure and Its Ability to Activate Lecithin:Cholesterol Acyltransferase. Diabetologia 2007, 50, 643-653. [CrossRef]

70. Esteve, E.; Ricart, W.; Fernández-Real, J.M. Dyslipidemia and Inflammation: An Evolutionary Conserved Mechanism. Clin. Nutr. 2005, 24, 16-31. [CrossRef] [PubMed]

71. De la Llera Moya, M.; McGillicuddy, F.C.; Hinkle, C.C.; Byrne, M.; Joshi, M.R.; Nguyen, V.; Tabita-Martinez, J.; Wolfe, M.L.; Badellino, K.; Pruscino, L.; et al. Inflammation Modulates Human HDL Composition and Function in Vivo. Atherosclerosis 2012, 222, 390-394. [CrossRef]

72. Jung, U.J.; Choi, M.S. Obesity and Its Metabolic Complications: The Role of Adipokines and the Relationship between Obesity, Inflammation, Insulin Resistance, Dyslipidemia and Nonalcoholic Fatty Liver Disease. Int. J. Mol. Sci. 2014, 15, 6184-6223. [CrossRef]

73. Montecucco, F.; Favari, E.; Norata, G.; Ronda, N. Impact of Systemic Inflammation and Autoinmmune Diseases on ApoA-I and HDL Plasma Levels and Functions. Handb. Exp. Pharmacol. 2015, 224, 455-482. [CrossRef]

74. Esposito, K.; Marfella, R.; Ciotola, M.; Di Palo, C.; Giugliano, F.; Giugliano, G.; D'Armiento, M.; D’Andrea, F.; Giugliano, D. Effect of a Mediterranean-Style Diet on Endothelial Dysfunction and Markers of Vascular Inflammation in the Metabolic Syndrome: A Randomized Trial. J. Am. Med. Assoc. 2004, 292, 1440-1446. [CrossRef]

75. Sun, L.; Li, E.; Wang, F.; Wang, T.; Qin, Z.; Niu, S.; Qiu, C. Quercetin Increases Macrophage Cholesterol Efflux to Inhibit Foam Cell Formation through Activating PPAR $\gamma$-ABCA1 Pathway. Int. J. Clin. Exp. Pathol. 2015, 8, 10854-10860.

76. Cui, Y.; Hou, P.; Li, F.; Liu, Q.; Qin, S.; Zhou, G.; Xu, X.; Si, Y.; Guo, S. Quercetin Improves Macrophage Reverse Cholesterol Transport in Apolipoprotein E-Deficient Mice Fed a High-Fat Diet. Lipids Health Dis. 2017, 16, 3-9. [CrossRef]

77. Helal, O.; Berrougui, H.; Loued, S.; Khalil, A. Extra-Virgin Olive Oil Consumption Improves the Capacity of HDL to Mediate Cholesterol Efflux and Increases ABCA1 and ABCG1 Expression in Human Macrophages. Br. J. Nutr. 2013, 109, 1844-1855. [CrossRef] [PubMed] 
78. Voloshyna, I.; Hai, O.; Littlefield, M.J.; Carsons, S.; Reiss, A.B. Resveratrol Mediates Anti-Atherogenic Effects on Cholesterol Flux in Human Macrophages and Endothelium via PPAR $\gamma$ and Adenosine. Eur. J. Pharmacol. 2013, 698, 299-309. [CrossRef]

79. Zhong, Y.; Feng, J.; Fan, Z.; Li, J. Curcumin Increases Cholesterol Efflux via Hemeoxygenase-1-Mediated ABCA1 and SR-BI Expression in Macrophages. Mol. Med. Rep. 2018, 17, 6138-6143. [CrossRef] [PubMed]

80. Elseweidy, M.M.; Younis, N.N.; Elswefy, S.E.; Abdallah, F.R.; El-Dahmy, S.I.; Elnagar, G.; Kassem, H.M. Atheroprotective Potentials of Curcuminoids against Ginger Extract in Hypercholesterolaemic Rabbits. Nat. Prod. Res. 2015, 29, 961-965. [CrossRef]

81. Hernáez, Á.; Sanllorente, A.; Castañer, O.; Martínez-González, M.Á.; Ros, E.; Pintó, X.; Estruch, R.; Salas-Salvadó, J.; Corella, D.; Alonso-Gómez, Á.M. Increased Consumption of Virgin Olive Oil, Nuts, Legumes, Whole Grains, and Fish Promotes HDL Functions in Humans. Mol. Nutr. Food Res. 2019, 63, 1800847. [CrossRef] [PubMed]

82. Chowaniec, Z.; Skoczyńska, A. Plasma Lipid Transfer Proteins: The Role of PLTP and CETP in Atherogenesis. Adv. Clin. Exp. Med. 2018, 27, 429-436. [CrossRef] [PubMed]

83. Fernández-Castillejo, S.; Rubio, L.; Hernáez, Á.; Catalán, Ú.; Pedret, A.; Valls, R.-M.; Mosele, J.I.; Covas, M.I.; Reamley, A.T.; Castañer, O.; et al. Determinants of HDL Cholesterol Efflux Capacity after Virgin Olive Oil Ingestion- Interrelationships with Fluidity of HDL Monolayer. Mol. Nutr. Food Res. 2017, 61, 1700445. [CrossRef]

84. Farràs, M.; Fernández-Castillejo, S.; Rubió, L.; Arranz, S.; Catalán, Ú.; Subirana, I.; Romero, M.P.; Castañer, O.; Pedret, A.; Blanchart, G.; et al. Phenol-Enriched Olive Oils Improve HDL Antioxidant Content in Hypercholesterolemic Subjects. A Randomized, Double-Blind, Cross-over, Controlled Trial. J. Nutr. Biochem. 2018, 51, 99-104. [CrossRef] [PubMed]

85. Fernández-Castillejo, S.; García-Heredia, A.I.; Solà, R.; Camps, J.; López de la Hazas, M.C.; Farràs, M.; Pedret, A.; Catalán, Ú.; Rubió, L.; Motilva, M.J.; et al. Phenol-Enriched Olive Oils Modify Paraoxonase-Related Variables: A Randomized, Crossover, Controlled Trial. Mol. Nutr. Food Res. 2017, 61, 1-39. [CrossRef]

86. Berryman, C.E.; Grieger, J.A.; West, S.G.; Chen, C.Y.O.; Blumberg, J.B.; Rothblat, G.H.; Sankaranarayanan, S.; Kris-Etherton, P.M. Acute Consumption of Walnuts and Walnut Components Differentially Affect Postprandial Lipemia, Endothelial Function, Oxidative Stress, and Cholesterol Efflux in Humans with Mild Hypercholesterolemia. J. Nutr. 2013, 143, 788-794. [CrossRef] [PubMed]

87. Tindall, A.M.; Kris-Etherton, P.M.; Petersen, K.S. Replacing Saturated Fats with Unsaturated Fats from Walnuts or Vegetable Oils Lowers Atherogenic Lipoprotein Classes Without Increasing Lipoprotein(A). J. Nutr. 2020, 150, 818-825. [CrossRef] [PubMed]

88. Ritcher, C.K.; Skulas-Ray, A.C.; Fleming, J.A.; Link, C.J.; Mukherjea, R.; Krul, E.S. Effects of Isoflavone-Containing Soya Protein on Ex Vivo Cholesterol Efflux, Vascular Function and Blood Markers of CVD Risk in Adults with Moderately Elevated Blood Pressure: A Dose - response Randomised Controlled Trial. Br. J. Nutr. 2017, 117, 1403-1413. [CrossRef]

89. Manninen, S.; Lankinen, M.; Erkkilä, A.; Nguyen, S.D.; Ruuth, M.; de Mello, V.; Öörni, K.; Schwab, U. The Effect of Intakes of Fish and Camelina Sativa Oil on Atherogenic and Anti-Atherogenic Functions of LDL and HDL Particles: A Randomized Controlled Trial. Atherosclerosis 2019, 281, 56-61. [CrossRef]

90. Yang, Z.H.; Amar, M.; Sorokin, A.V.; Troendle, J.; Courville, A.B.; Sampson, M.; Playford, M.P.; Yang, S.; Stagliano, M.; Ling, C.; et al. Supplementation with Saury Oil, a Fish Oil High in Omega-11 Monounsaturated Fatty Acids, Improves Plasma Lipids in Healthy Subjects. J. Clin. Lipidol. 2020, 14, 53-65.e2. [CrossRef]

91. Nicod, N.; Chiva-Blanch, G.; Giordano, E.; Dávalos, A.; Parker, R.S.; Visioli, F. Green Tea, Cocoa, and Red Wine Polyphenols Moderately Modulate Intestinal Inflammation and Do Not Increase High-Density Lipoprotein (HDL) Production. J. Agric. Food Chem. 2014, 62, 2228-2232. [CrossRef]

92. Millar, C.L.; Duclos, Q.; Garcia, C.; Norris, G.H.; Lemos, B.S.; DiMarco, D.M.; Fernandez, M.L. Effects of Freeze-Dried Grape Powder on High-Density Lipoprotein Function in Adults with Metabolic Syndrome: A Randomized Controlled Pilot Study. Metab. Syndr. Relat. Disord. 2018, 16, 464-469. [CrossRef]

93. Marín-Echeverri, C.; Blesso, C.N.; Fernández, M.L.; Galvis-Pérez, Y.; Ciro-Gómez, G.; Nuñez-Rangel, V.; Aristizábal, J.C.; BaronaAcevedo, J. Effect of Agraz (Vaccinium Meridionale Swartz) on High-Density Lipoprotein Function and Inflammation in Women with Metabolic Syndrome. Antioxidants 2018, 7, 185. [CrossRef] [PubMed]

94. Michaličková, D.; Belović, M.; Ilić, N.; Kotur-Stevuljević, J.; Slanař, O.; Šobajić, S. Comparison of Polyphenol-Enriched Tomato Juice and Standard Tomato Juice for Cardiovascular Benefits in Subjects with Stage 1 Hypertension: A Randomized Controlled Study. Plant. Foods Hum. Nutr. 2019, 74, 122-127. [CrossRef]

95. Lazavi, F.; Mirmiran, P.; Sohrab, G.; Nikpayam, O.; Angoorani, P.; Hedayati, M. The Barberry Juice Effects on Metabolic Factors and Oxidative Stress in Patients with Type 2 Diabetes: A Randomized Clinical Trial. Complement. Ther. Clin. Pract. 2018, 31, 170-174. [CrossRef]

96. Balsan, G.; Pellanda, L.C.; Sausen, G.; Galarraga, T.; Zaffari, D.; Pontin, B.; Portal, V.L. Effect of Yerba Mate and Green Tea on Paraoxonase and Leptin Levels in Patients Affected by Overweight or Obesity and Dyslipidemia: A Randomized Clinical Trial. Nutr. J. 2019, 18, 1-10. [CrossRef] [PubMed]

97. Talbot, C.P.J.; Mensink, R.P.; Smolders, L.; Bakeroot, V.; Plat, J. Theobromine Does Not Affect Fasting and Postprandial HDL Cholesterol Efflux Capacity, While It Decreases Fasting MiR-92a Levels in Humans. Mol. Nutr. Food Res. $2018,62,1800027$. [CrossRef] [PubMed]

98. Tabatabaie, M.; Abdollahi, S.; Salehi-Abargouei, A.; Clark, C.C.T.; Karimi-Nazari, E.; Fallahzadeh, H.; Rahmanian, M.; MozaffariKhosravi, H. The Effect of Resveratrol Supplementation on Serum Levels of Asymmetric De-Methyl-Arginine and Paraoxonase 1 Activity in Patients with Type 2 Diabetes: A Randomized, Double-Blind Controlled Trial. Phyther. Res. 2020, 34, 2023-2031. [CrossRef] 
99. Patel, R.V.; Mistry, B.M.; Shinde, S.K.; Syed, R.; Singh, V.; Shin, H.S. Therapeutic Potential of Quercetin as a Cardiovascular Agent. Eur. J. Med. Chem. 2018, 155, 889-904. [CrossRef] [PubMed]

100. Catalán, Ú.; López de las Hazas, M.C.; Rubió, L.; Fernández-Castillejo, S.; Pedret, A.; de la Torre, R.; Motilva, M.J.; Solà, R. Protective Effect of Hydroxytyrosol and Its Predominant Plasmatic Human Metabolites against Endothelial Dysfunction in Human Aortic Endothelial Cells. Mol. Nutr. Food Res. 2015, 59, 2523-2536. [CrossRef]

101. Derosa, G.; Catena, G.; Raddino, R.; Gaudio, G.; Maggi, A.; D'Angelo, A.; Maffioli, P. Effects on Oral Fat Load of a Nutraceutical Combination of Fermented Red Rice, Sterol Esters and Stanols, Curcumin, and Olive Polyphenols: A Randomized, Placebo Controlled Trial. Phytomedicine 2018, 42, 75-82. [CrossRef] [PubMed]

102. Gliemann, L.; Schmidt, J.F.; Olesen, J.; Biensø, R.S.; Peronard, S.L.; Grandjean, S.U.; Mortensen, S.P.; Nyberg, M.; Bangsbo, J.; Pilegaard, H.; et al. Resveratrol Blunts the Positive Effects of Exercise Training on Cardiovascular Health in Aged Men. J. Physiol. 2013, 591, 5047-5059. [CrossRef] [PubMed]

103. Anastasius, M.; Kockx, M.; Jessup, W.; Sullivan, D.; Rye, K.A.; Kritharides, L. Cholesterol Efflux Capacity: An Introduction for Clinicians. Am. Heart J. 2016, 180, 54-63. [CrossRef]

104. Wynn, T.A.; Chawla, A.; Pollard, J.W. Origins and Hallmarks of Macrophages: Development, Homeostasis, and Disease. Nature 2013, 496, 445-455. [CrossRef]

105. Marcelino, G.; Hiane, P.A.; de Freitas, K.C.; Santana, L.F.; Pott, A.; Donadon, J.R.; de Guimarães, R.C.A. Effects of Olive Oil and Its Minor Components on Cardiovascular Diseases, Inflammation, and Gut Microbiota. Nutrients 2019, 11, 1826. [CrossRef]

106. Gorzynik-Debicka, M.; Przychodzen, P.; Cappello, F.; Kuban-Jankowska, A.; Gammazza, A.M.; Knap, N.; Wozniak, M.; GorskaPonikowska, M. Potential Health Benefits of Olive Oil and Plant Polyphenols. Int. J. Mol. Sci. 2018, 19, 686. [CrossRef]

107. Hunter, P.M.; Hegele, R.A. Functional Foods and Dietary Supplement for the Management of Dyslipidemia. Nat. Rev. 2017, 13, 278-288. [CrossRef]

108. Hoseini, A.; Namazi, G.; Farrokhian, A.; Reiner, Ž.; Aghadavod, E.; Bahmani, F.; Asemi, Z. The Effects of Resveratrol on Metabolic Status in Patients with Type 2 Diabetes Mellitus and Coronary Heart Disease. Food Funct. 2019, 10, 6042-6051. [CrossRef]

109. Batista-Jorge, G.C.; Barcala-Jorge, A.S.; Silveira, M.F.; Lelis, D.F.; Andrade, J.M.O.; de Paula, A.M.B.; Guimarães, A.L.S.; Santos, S.H.S. Oral Resveratrol Supplementation Improves Metabolic Syndrome Features in Obese Patients Submitted to a LifestyleChanging Program. Life Sci. 2020, 256, 117962. [CrossRef] [PubMed]

110. Kjær, T.N.; Ornstrup, M.J.; Poulsen, M.M.; Stødkilde-Jørgensen, H.; Jessen, N.; Jørgensen, J.O.L.; Richelsen, B.; Pedersen, S.B. No Beneficial Effects of Resveratrol on the Metabolic Syndrome: A Randomized Placebo-Controlled Clinical Trial. J. Clin. Endocrinol. Metab. 2017, 102, 1642-1651. [CrossRef] [PubMed]

111. Bitok, E.; Sabaté, J. Nuts and Cardiovascular Disease. Prog. Cardiovasc. Dis. 2018, 61, 33-37. [CrossRef]

112. Bouchenak, M.; Lamri-Senhadji, M. Nutritional Quality of Legumes, and Their Role in Cardiometabolic Risk Prevention: A Review. J. Med. Food 2013, 16, 185-198. [CrossRef] [PubMed]

113. Zhu, F.; Du, B.; Xu, B. Anti-Inflammatory Effects of Phytochemicals from Fruits, Vegetables, and Food Legumes: A Review. Crit. Rev. Food Sci. Nutr. 2018, 58, 1260-1270. [CrossRef] [PubMed]

114. Kim, H.S.; Quon, M.J.; Kim, J.A. New Insights into the Mechanisms of Polyphenols beyond Antioxidant Properties; Lessons from the Green Tea Polyphenol, Epigallocatechin 3-Gallate. Redox Biol. 2014, 2, 187-195. [CrossRef]

115. Magrone, T.; Russo, M.A.; Jirillo, E. Cocoa and Dark Chocolate Polyphenols: From Biology to Clinical Applications. Front. Immunol. 2017, 8, 677. [CrossRef]

116. Castaldo, L.; Narváez, A.; Izzo, L.; Graziani, G.; Gaspari, A.; Di Minno, G.; Ritieni, A. Red Wine Consumption and Cardiovascular Health. Molecules 2019, 24, 3626. [CrossRef] [PubMed]

117. Ganjali, S.; Blesso, C.N.; Banach, M.; Pirro, M.; Majeed, M.; Sahebkar, A. Effects of Curcumin on HDL Functionality. Pharmacol. Res. 2017, 119, 208-218. [CrossRef] [PubMed]

118. Tsuda, T. Curcumin as a Functional Food-Derived Factor: Degradation Products, Metabolites, Bioactivity, and Future Perspectives. Food Funct. 2018, 9, 705-714. [CrossRef] [PubMed]

119. Kelly, G.S. Quercitin. Dict. Gems Gemol. 2009, 16, 172-195. [CrossRef] 